\title{
Mantle heterogeneity through Zn systematics in oceanic basalts: Evidence for a deep carbon cycling
}

\author{
Hugues Beunon ${ }^{\mathrm{a}, *}$, Nadine Mattielli ${ }^{\mathrm{a}}$, Luc S. Doucet ${ }^{\mathrm{b}}$, Bertrand Moine ${ }^{\mathrm{c}}$, Baptiste Debret $^{\mathrm{a}, \mathrm{d}}$ \\ ${ }^{\mathrm{a}}$ Laboratoire G-Time, DGES, ULB, Université Libre de Bruxelles, Av. Roosevelt 50, CP 160/02, 1050 Brussels, Belgium \\ ${ }^{\mathrm{b}}$ Earth Dynamics Research Group, TIGeR, Department of Applied Geology, Curtin University Perth, WA 6148, Australia \\ ${ }^{\mathrm{c}}$ UJM Saint-Etienne, UCA, CNRS, IRD, Laboratoire Magmas et Volcans UMR6524, Université de Lyon, F42023 Saint-Etienne, France \\ ${ }^{\mathrm{d}}$ Institut de physique du globe de Paris, CNRS, Université de Paris, Paris, France
}

\section{A R T I C L E I N F O}

\section{Keywords:}

Zinc

Zinc isotopes

Radiogenic isotopes

Mantle heterogeneity

OIB

MORB

Deep carbon cycle

\begin{abstract}
A B S T R A C T
Subduction at convergent margins introduces a range of sedimentary and crustal materials into the mantle, providing the most dominant form of heterogeneity in the source of oceanic basalts. Yet, the relationship between geochemical variability and lithologic heterogeneities in the Earth's mantle remains controversial. In this paper, we comprehensively review $\mathrm{Zn}, \delta^{66} \mathrm{Zn}$ and $\mathrm{Sr}-\mathrm{Nd}$ isotope systematics in near-primary basalts erupted at mid-ocean ridges (MORB) and ocean islands (OIB) to help constrain the nature and proportion of the carbon (C) bearing slab-derived component in their mantle sources. We show that $\mathrm{Zn}$ elemental and isotopic composition of oceanic basalts differs according to their tectonic settings, increasing from MORB ( $\mathrm{Zn}=62 \pm 10$ to $73 \pm 11 \mathrm{ppm} ; \delta^{66} \mathrm{Zn}=+0.24 \pm 0.01$ to $+0.31 \pm 0.02 \%$ ) to OIB ( $\mathrm{Zn}=74 \pm 9$ to $124 \pm 7 \mathrm{ppm}$; $\delta^{66} \mathrm{Zn}=+0.21 \pm 0.07$ to $+0.40 \pm 0.04 \%$ ). Unlike MORB, the high $\mathrm{Zn}$ and $\delta^{66} \mathrm{Zn}$ recorded in OIB cannot be explained by partial melting of a fertile peridotite mantle source only. Importantly, global correlations between $\mathrm{Zn}$ content and Sr-Nd isotopes in oceanic basalts suggest that the $\mathrm{Zn}$ enrichment in OIB is inherited from a recycled component in their mantle source rather than melting processes. We demonstrate that involvement of neither typical MORB-like oceanic crust nor subducted sediments can achieve the whole range of Zn composition in OIB. Instead, addition of $\leq 6 \%$ C-bearing oceanic crust to a fertile peridotite mantle fully resolves the $\mathrm{Zn}$ heterogeneity of OIB, both in terms of magnitude of Zn enrichment and global trends with Sr-Nd isotopes. Such scenario is corroborated by the elevated $\delta^{66} \mathrm{Zn}$ of OIB relative to MORB and mantle peridotites, reflecting the contribution of isotopically heavy C-bearing phases $\left(\delta^{66} \mathrm{Zn}=+0.91 \pm 0.24 \%\right.$ ) to the mantle source $\left(\delta^{66} \mathrm{Zn}=+0.16 \pm 0.06 \%\right)$. Our study thus emphasizes the use of $\mathrm{Zn}$ and $\delta^{66} \mathrm{Zn}$ systematics to track the nature and origin of mantle carbon, highlighting the role of subduction in the deep carbon cycle. Finally, the positive correlation between $\mathrm{Zn}$ content and temperature of magma generation of oceanic basalts suggests that hotter mantle plumes are more likely to carry a higher proportion of dense C-bearing eclogite. Zinc systematics therefore may provide evidence that the presence of heterogeneous domains in the source of OIB is, at least partly, linked to plume thermal buoyancy, bringing new insights into mantle dynamics.
\end{abstract}

\section{Introduction}

Geophysical and geochemical heterogeneities have long been recognized within the Earth's mantle. The latter was initially inferred from trace elements, and long-lived radiogenic isotopes (e.g., Sr, Nd, Hf, $\mathrm{Pb}$ ) variations in basalts erupted at mid-ocean ridges (MORB) and ocean islands (OIB). Their geochemical signature reflects the compositional heterogeneity of the mantle and its evolution through time (e.g., Hofmann, 1997; Willbold and Stracke, 2006; Zindler and Hart, 1986). It is widely accepted that these heterogeneities involve ancient and deeply subducted sediments, oceanic crust and underlying lithosphere introduced in the mantle at convergent margins. Eclogites (i.e., olivinefree, clinopyroxene- and garnet-bearing rocks) derived from the recycled oceanic crust and sediments are then entrained and stirred by convection, providing one of the most dominant form of heterogeneity in the mantle source of oceanic basalts. However, the specific nature and proportion of the slab-derived eclogitic component in the mantle is still a matter of speculation (see Anderson, 2006 and references therein). Subducted eclogites may derive from a typical MORB oceanic crust (e.g., silica-excess and volatile-free, hereafter referred as MORB-

\footnotetext{
* Corresponding author.

E-mail address: hbeunon@ulb.ac.be (H. Beunon).
} 
Table 1

Average $\mathrm{Zn}$ concentration $(\mathrm{ppm}), \mathrm{Zn} / \mathrm{Fe}$ ratio, $\mathrm{MgO}(\mathrm{wt} \%), \mathrm{FeO}^{\mathrm{T}}$ (wt\%) and $\mathrm{Sr}-\mathrm{Nd}$ isotopic composition in peridotites and near-primary basalts from selected locations.

\begin{tabular}{|c|c|c|c|c|c|c|c|}
\hline Sample type & $\mathrm{Zn}(\mathrm{ppm})$ & $\mathrm{Zn} / \mathrm{Fe}\left(\mathrm{x} 10^{4}\right)$ & $\mathrm{MgO}(w \mathrm{t} \%)$ & $\mathrm{FeO}^{\mathrm{T}}(\mathrm{wt} \%)$ & ${ }^{86} \mathrm{Sr} /{ }^{87} \mathrm{Sr}$ & ${ }^{143} \mathrm{Nd} /{ }^{144} \mathrm{Nd}$ & $\mathrm{T}_{\text {Lee }}\left({ }^{\circ} \mathrm{C}\right)$ \\
\hline Peridotites & $52 \pm 9$ & $8.2 \pm 1.3$ & $42.8 \pm 2.7$ & $8.1 \pm 0.7$ & - & - & - \\
\hline Lherzolites & $54 \pm 8$ & $8.5 \pm 1.2$ & $41.6 \pm 2.1$ & $8.2 \pm 0.7$ & - & - & - \\
\hline Harzburgites & $48 \pm 8$ & $7.8 \pm 1.3$ & $45.5 \pm 1.6$ & $8.0 \pm 0.6$ & - & - & - \\
\hline MORB & $68 \pm 12$ & $9.6 \pm 1.5$ & $9.7 \pm 1.1$ & $9.0 \pm 1.0$ & $0.70284 \pm 31$ & $0.51308 \pm 10$ & - \\
\hline EPR & $62 \pm 10$ & $9.0 \pm 1.6$ & $9.9 \pm 1.3$ & $8.6 \pm 1.3$ & $0.70254 \pm 9$ & $0.51314 \pm 5$ & $1371 \pm 41$ \\
\hline Gakkel & $64 \pm 2$ & $9.2 \pm 0.6$ & $9.1 \pm 0.1$ & $9.0 \pm 0.6$ & $0.70290 \pm 6$ & $0.51312 \pm 8$ & $1387 \pm 42$ \\
\hline MAR & $70 \pm 12$ & $9.8 \pm 1.4$ & $9.8 \pm 1.2$ & $9.2 \pm 0.9$ & $0.70291 \pm 28$ & $0.51307 \pm 10$ & $1412 \pm 42$ \\
\hline SEIR & $70 \pm 13$ & $9.4 \pm 1.2$ & $9.4 \pm 0.3$ & $9.6 \pm 1.4$ & $0.70305 \pm 26$ & $0.51307 \pm 12$ & - \\
\hline SWIR & $73 \pm 11$ & $10.2 \pm 1.0$ & $9.4 \pm 0.3$ & $9.2 \pm 1.0$ & $0.70322 \pm 38$ & $0.51299 \pm 7$ & $1391 \pm 42$ \\
\hline MORB-related OIB & $79 \pm 13$ & $10.1 \pm 1.0$ & $11.0 \pm 1.4$ & $10.1 \pm 0.9$ & $0.70357 \pm 68$ & $0.51296 \pm 14$ & - \\
\hline Iceland & $74 \pm 9$ & $9.7 \pm 0.7$ & $11.2 \pm 1.3$ & $9.7 \pm 0.8$ & $0.70317 \pm 16$ & $0.51305 \pm 6$ & $1431 \pm 43$ \\
\hline Galapagos & $84 \pm 15$ & $10.5 \pm 1.3$ & $10.4 \pm 1.4$ & $10.2 \pm 0.9$ & $0.70310 \pm 30$ & $0.51302 \pm 6$ & $1462 \pm 44$ \\
\hline Azores & $86 \pm 10$ & $10.7 \pm 1.2$ & $10.9 \pm 1.7$ & $10.4 \pm 0.7$ & $0.70367 \pm 32$ & $0.51290 \pm 5$ & $1477 \pm 44$ \\
\hline Kerguelen & $94 \pm 8$ & $10.5 \pm 0.8$ & $10.7 \pm 1.2$ & $11.5 \pm 0.5$ & $0.70484 \pm 37$ & $0.51270 \pm 9$ & $1514 \pm 45$ \\
\hline OIB & $108 \pm 15$ & $11.6 \pm 1.7$ & $11.3 \pm 1.7$ & $12.0 \pm 0.9$ & $0.70414 \pm 98$ & $0.51284 \pm 12$ & - \\
\hline St Helena & $93 \pm 7$ & $9.7 \pm 0.5$ & $11.8 \pm 1.8$ & $12.3 \pm 0.6$ & $0.70288 \pm 5$ & $0.51287 \pm 3$ & $1587 \pm 48$ \\
\hline Mascarene & $102 \pm 13$ & $10.7 \pm 1.5$ & $11.1 \pm 1.5$ & $12.3 \pm 1.0$ & $0.70398 \pm 20$ & $0.51288 \pm 5$ & $1565 \pm 47$ \\
\hline Hawaii & $103 \pm 13$ & $11.3 \pm 1.6$ & $10.8 \pm 1.6$ & $11.7 \pm 0.8$ & $0.70362 \pm 14$ & $0.51293 \pm 8$ & $1521 \pm 46$ \\
\hline Pitcairn & $106 \pm 13$ & $12.0 \pm 1.8$ & $12.2 \pm 1.8$ & $11.5 \pm 0.6$ & $0.70468 \pm 27$ & $0.51257 \pm 7$ & $1522 \pm 46$ \\
\hline Canary & $108 \pm 16$ & $11.3 \pm 1.5$ & $11.2 \pm 1.6$ & $12.3 \pm 1.0$ & $0.70320 \pm 17$ & $0.51294 \pm 3$ & $1577 \pm 47$ \\
\hline Cape Verde & $110 \pm 8$ & $12.7 \pm 1.0$ & $12.1 \pm 1.7$ & $11.1 \pm 0.5$ & $0.70341 \pm 6$ & $0.51277 \pm 3$ & $1540 \pm 46$ \\
\hline Comoros & $110 \pm 14$ & $11.5 \pm 1.4$ & $11.1 \pm 0.4$ & $12.3 \pm 0.2$ & $0.70348 \pm 15$ & $0.51279 \pm 6$ & $1590 \pm 48$ \\
\hline Cook-Austral & $114 \pm 15$ & $12.1 \pm 1.5$ & $12.4 \pm 1.4$ & $12.3 \pm 0.7$ & $0.70310 \pm 40$ & $0.51290 \pm 5$ & $1594 \pm 48$ \\
\hline Marquesas & $117 \pm 6$ & $12.7 \pm 0.6$ & $11.5 \pm 2.0$ & $11.8 \pm 0.6$ & $0.70412 \pm 56$ & $0.51284 \pm 2$ & $1536 \pm 46$ \\
\hline Society & $124 \pm 7$ & $13.3 \pm 0.7$ & $12.2 \pm 1.7$ & $12.0 \pm 0.9$ & $0.70502 \pm 61$ & $0.51274 \pm 6$ & $1566 \pm 47$ \\
\hline Samoa & $124 \pm 12$ & $13.1 \pm 1.1$ & $11.8 \pm 1.4$ & $12.2 \pm 1$ & $0.70562 \pm 69$ & $0.51273 \pm 5$ & $1572 \pm 47$ \\
\hline
\end{tabular}

Average temperature of magma generation $\left(\mathrm{T}_{\mathrm{Lee}}\right)$ calculated from the thermometer of Lee et al. (2009) are also given. Error is given as standard deviation. See Appendix 1 for the whole dataset and references.

eclogite) that can be carbonatized during seafloor hydrothermal alteration (e.g., silica-deficient and carbon-bearing, hereafter referred as C-bearing eclogites; Nakamura and Kato, 2004; Kitajima et al., 2001). However, little is known about the relationship between geochemical variability and lithologic heterogeneities in the Earth's mantle. While incompatible trace element variations highlight distinct geochemical imprints between MORB and OIB, they do not provide information about the exact nature and extent of mineralogical variability in the source regions of oceanic basalts. Yet, characterization of such lithologic heterogeneities is of prime importance for constraining the physical properties of the mantle (e.g., thermal state, viscosity and density), understanding the dynamics of the Earth (e.g., differentiation and melting processes) and bridging geochemical and geophysical observations. Several studies have tried to tackle the question of mineralogical heterogeneities in the mantle focusing on major oxide (Dasgupta et al., 2010; Jackson and Dasgupta, 2008; Sobolev et al., 2005, 2007; Prytulak and Elliott, 2007), moderately incompatible firstrow transition element (FRTEs, e.g., Zn/Fe, Fe/Mn, Ni; Le Roux et al., 2010, 2011, 2015; Humayun, 2004; Sobolev et al., 2007) and nontraditional stable isotope systematics (Williams and Bizimis, 2014; Pringle et al., 2016; Krienitz et al., 2012) in mantle rocks and mantlerelated melts. Among the FRTEs, Zn has been subject to a growing interest for tracing eclogite fragments in the mantle through $\mathrm{Zn} / \mathrm{Fe}$ ratio systematics in oceanic basalts (Le Roux et al., 2010, 2011, 2015). In parallel, recent studies have also shown the great potential of some metal stable isotopes, including $\mathrm{Zn}$, as sensitive tracers of the Deep Carbon Cycle (DCC) since carbonates and Bulk Silicate Earth display very distinct isotopic compositions $\left(\delta^{66} \mathrm{Zn}_{\text {carbonates }}=+0.91 \pm 0.24 \%\right.$ o and $\delta^{66} \mathrm{Zn}_{\mathrm{BSE}}=+0.16 \pm 0.06 \%$ using the per mille deviation of ${ }^{66} \mathrm{Zn} /{ }^{64} \mathrm{Zn}$ from the JMC-Lyon standard, Liu et al., 2016; Pichat et al., 2003; Sossi et al., 2018; Liu and Li, 2019; Debret et al., 2018a). The concomitant use of $\mathrm{Zn}$ and $\delta^{66} \mathrm{Zn}$ offers some interesting possibilities to distinguish between MORB-eclogite and C-bearing eclogite contribution in the source of oceanic basalts.

In this paper, we present a comprehensive review of $\mathrm{Zn}, \delta^{66} \mathrm{Zn}$ and Sr-Nd isotope systematics in near-primary oceanic basalts worldwide and reassess the use of $\mathrm{Zn}$ as a tracer of eclogite-derived melts. We show that $\mathrm{Zn}$ abundances correlate with $\mathrm{Sr}$-Nd isotopes on a single ridge and ocean island group basis. This result, together with the extreme $\mathrm{Zn}$ enrichment in OIB cannot be readily explained by melting and mixing of fertile peridotite and MORB-eclogite as previously suggested. Instead, our results point towards the involvement of Zn-rich C-bearing eclogites. On the basis of a compilation of $\mathrm{Zn}$ isotopic data from previous studies and new unpublished data from the Crozet archipelago, we argue that such scenario is corroborated by the heavy $\delta^{66} \mathrm{Zn}$ of OIB relative to MORB and mantle peridotites. Thus, Zn systematics may provide a valuable tool to fingerprint recycling of C-bearing subducted materials and deep carbon cycling in the Earth's mantle.

\section{Materials and methods}

\subsection{Data selection and filtering}

We compiled zinc abundances, major oxide concentrations and radiogenic Sr-Nd isotopic composition of oceanic basalts from the GEOROC (http://georoc.mpch-mainz.gwdg.de/georoc) and PetDB (www.earthcem.org/petdb) databases. Basalts with LOI > $3 \mathrm{wt} \%$ and sum of oxides $<97 \mathrm{wt} \%$ or $>102 \mathrm{wt} \%$ calculated on a dry basis were systematically excluded from the filtered database. Major element contents of the remaining samples were then normalized to $100 \mathrm{wt} \%$ on a dry-weight basis with all $\mathrm{Fe}$ reported as $\mathrm{FeO}^{\mathrm{T}}$. Since we aim to picture global-scale variations in oceanic basalts (i.e., MORB and OIB), average near-primary compositions were calculated on a single ridge and ocean island group basis when Zn data availability was sufficient (here arbitrary set to $>8$ samples). Only the most primitive samples with $9 \mathrm{wt}$ $\%<\mathrm{MgO}<16 \mathrm{wt} \%$ were considered to limit the effect of olivine accumulation and crystal fractionation (filtering scheme adapted from Jackson and Dasgupta, 2008, see also Section 3.1 for further discussion on the effect of fractional crystallization). The final filtered database includes near-primary MORB $(n=285)$ from the Mid-Atlantic Ridge (MAR), South-East Indian Ridge (SEIR), South-West Indian Ridge (SWIR), Gakkel Ridge (GAK) and East Pacific Rise (EPR) and OIB 
( $n=694$ ) from Iceland, Hawaii, the Azores, Kerguelen, Galapagos, Samoan, Society, Marquesas, Mascarene, Cook-Austral, Comoros, Cape Verde, Canary, Pitcairn and St Helena Islands. We also compiled Zn data of fertile lherzolites $(n=269)$ and residual harzburgites $(n=124)$ from the GEOROC database (http://georoc.mpch-mainz.gwdg.de/ georoc, petrological names as given in the GEOROC database). Because $\mathrm{Zn}$ elemental composition may have been modified during secondary processes such as serpentinization (Debret et al., 2018b) peridotites with loss on ignition (LOI) $>3 \mathrm{wt} \%$ were discarded from our compilation. Average composition of peridotites and oceanic basalts from distinct ridges and ocean islands are summarized in Table 1 (see Appendix 1 for the whole filtered dataset and references).

Published $\mathrm{Zn}$ isotopic compositions of oceanic basalts are much more sparse in comparison to $\mathrm{Zn}$ elemental data precluding a detailed examination of $\delta^{66} \mathrm{Zn}$ variations on a single ridge or oceanic island basis. Here we compiled a dataset of $47 \delta^{66} \mathrm{Zn}$ values including MORB $(n=13)$ from the MAR, SEIR, SWIR, Gakkel ridge and Carlsberg ridge and OIB $(n=34)$ from Hawaii, Iceland, the Canary and Reunion islands (see Appendix 2 for the whole dataset and references). Given the limited $\delta^{66} \mathrm{Zn}$ fractionation during fractional crystallization (see Section 3.1 ) and the limited availability of data, we consider a slightly expanded range of $\mathrm{MgO}$ for near-primary basalts $(6 \mathrm{wt} \%<\mathrm{MgO}<$ $16 \mathrm{wt} \%)$ totaling $24 \delta^{66} \mathrm{Zn}$ values for undifferentiated oceanic basalts worldwide (Table 2).

\subsection{Acquisition of new $\mathrm{Zn}$ and $\delta^{66} \mathrm{Zn}$ data from Crozet Archipelago}

New $\delta^{66} \mathrm{Zn}$ MC-ICP-MS data and associated Zn concentrations determined by ICP-MS in 11 basaltic samples from the Penguins island (Crozet Archipelago) were also determined to expand the pre-existing database (Table 2, see Appendix 3 for detailed results). Petrographic and geochemical characterization of the selected samples including major and other trace elements data are available in Breton et al. (2013). Measurements were carried out on bulk-rock powders at the Laboratoire G-Time, Université Libre de Bruxelles (ULB). About $50 \mathrm{mg}$ of powdered samples were dissolved using a 3:2 mix of concentrated HF and $\mathrm{HNO}_{3}$ in square bodied Teflon vials (C) Savillex) at $130{ }^{\circ} \mathrm{C}$ on a hotplate. Samples were then dried down and further attacked with a 1:1 mix of concentrated $\mathrm{HCl}$ and $\mathrm{HNO}_{3}$. All reagents were distilled in subboiling Teflon two-bottle stills at the ULB. After total digestion samples were split into two aliquots and $\mathrm{Zn}$ concentrations were analyzed in $5 \% \mathrm{HNO}_{3}$ by Inductively Coupled Plasma Mass Spectrometry (ICP-MS, (C) Agilent $7700 \times$ ). The total procedural blank contribution was $<6 \mathrm{ng}$ for $\mathrm{Zn}$ which is negligible with respect to the total amount of $\mathrm{Zn}$ in the samples (blank contribution $<<1 \%$ ). Geological reference materials BHVO-2 and BCR-2 (basalts, USGS) were processed through chemistry and analyzed alongside samples. Total duplicates of sample OVPG-13 yielded standard deviation of $\pm 2.5 \mathrm{ppm}$ (2SD).

$\mathrm{Zn}$ isotopic analyses were carried out on a Nu Plasma II multi-collector ICP-MS (MC-ICP-MS, (C) Nu Instruments) using the remaining aliquot and following the procedure of Petit et al. (2008), adapted from Maréchal et al. (1999). Quantitative purification of $\mathrm{Zn}$ from the matrix was achieved by chromatographic exchange using ion exchange resin AG1x8 (200-400 mesh) and $0.8 \times 4 \mathrm{~cm}$ Teflon columns (yield $\geq 99 \%$, Sossi et al., 2015). The total procedural blank after dissolution and purification was $<6 \mathrm{ng}$ for $\mathrm{Zn}$ (blank contribution $<<1 \%$ ). Analyses were performed in wet plasma mode with plasma shield, and instrumental mass bias was corrected by sample-standard bracketing and external normalization using an in-house $\mathrm{Cu}$ doping solution. Dried $\mathrm{Zn}$ fractions were dissolved in $100 \mu \mathrm{L}$ of concentrated $\mathrm{HNO}_{3}$ and then diluted at $400 \mathrm{ppb}$ in $0.05 \mathrm{M} \mathrm{HNO}_{3}$ for analyses. All $\mathrm{Zn}$ and $\mathrm{Cu}$ masses $\left({ }^{64} \mathrm{Zn},{ }^{66} \mathrm{Zn},{ }^{67} \mathrm{Zn},{ }^{68} \mathrm{Zn},{ }^{70} \mathrm{Zn}\right.$ and $\left.{ }^{63} \mathrm{Cu},{ }^{65} \mathrm{Cu}\right)$ were monitored as well as ${ }^{62} \mathrm{Ni}$ to avoid interference between ${ }^{64} \mathrm{Ni}$ and ${ }^{64} \mathrm{Zn}$. However, the ${ }^{62} \mathrm{Ni}$ beam intensity was systematically lower than the background signal $\left(\leq 1.10^{-4} \mathrm{~V}\right)$ indicating complete Ni separation from the analyzed solutions. Our in-house standard used for sample-standard bracketing is
Table 2

$\mathrm{Zn}$ concentration (ppm), $\delta^{66} \mathrm{Zn}(\% 0)$ and $\mathrm{MgO}(\mathrm{wt} \%)$ in near-primary oceanic basalts worldwide compiled from the literature ( ${ }^{\mathrm{a} W a n g}$ et al., 2017; ${ }^{\mathrm{b}} \mathrm{Huang}$ et al., 2018a; ${ }^{\mathrm{c} C h e n ~ e t ~ a l ., ~ 2013 ; ~}{ }^{\mathrm{d}}$ Georem) and basaltic samples from Crozet Archipelago analyzed in this study.

\begin{tabular}{|c|c|c|c|}
\hline Sample & Zn (ppm) & $\delta^{66} \mathrm{Zn}(\%)$ & $\mathrm{MgO}(\mathrm{wt} \%)$ \\
\hline \multicolumn{4}{|l|}{ Carlsberg ridge } \\
\hline $\mathrm{CR}_{01-1^{\mathrm{a}}}$ & 83 & $+0.29 \pm 0.04$ & 8.4 \\
\hline $\mathrm{CR}_{02}-1^{\mathrm{a}}$ & 85 & $+0.27 \pm 0.04$ & 7.6 \\
\hline $\mathrm{CR} 03-3^{\mathrm{a}}$ & 77 & $+0.30 \pm 0.03$ & 9.2 \\
\hline CR04-1 $^{\mathrm{a}}$ & 81 & $+0.26 \pm 0.01$ & 8.4 \\
\hline \multicolumn{4}{|l|}{ North Atlantic ridge } \\
\hline AR04-1 ${ }^{\mathrm{a}}$ & 82 & $+0.28 \pm 0.03$ & 8.3 \\
\hline AR05-1 ${ }^{\mathrm{a}}$ & 81 & $+0.28 \pm 0.03$ & 6.7 \\
\hline \multicolumn{4}{|l|}{ Gakkel ridge } \\
\hline HLY0102-023-027 b & 76 & $+0.27 \pm 0.03$ & 7.6 \\
\hline HLY0102-038-029 ${ }^{\mathrm{b}}$ & 67 & $+0.26 \pm 0.01$ & 7.6 \\
\hline HLY0102-053-21 ${ }^{\mathrm{b}}$ & 75 & $+0.30 \pm 0.02$ & 8.3 \\
\hline \multicolumn{4}{|l|}{ South East Indian ridge } \\
\hline VEM0033-1-001-002 ${ }^{\mathrm{b}}$ & 83 & $+0.31 \pm 0.01$ & 6.9 \\
\hline VEM0033-1-005-005 ${ }^{\mathrm{b}}$ & 66 & $+0.25 \pm 0.02$ & 8.7 \\
\hline VEM0033-1-003-004 & 76 & $+0.24 \pm 0.02$ & 8.5 \\
\hline \multicolumn{4}{|l|}{ Canary } \\
\hline La Palma $1971^{\mathrm{a}}$ & 123 & $+0.29 \pm 0.04$ & 7.7 \\
\hline \multicolumn{4}{|l|}{ Reunion } \\
\hline REU $140825-38^{\mathrm{a}}$ & 116 & $+0.36 \pm 0.04$ & 6.8 \\
\hline REU $140825-41^{\mathrm{a}}$ & 124 & $+0.32 \pm 0.04$ & 9.2 \\
\hline REU $140825-45^{\mathrm{a}}$ & 116 & $+0.29 \pm 0.04$ & 9.9 \\
\hline REU $140829-71^{\mathrm{a}}$ & 111 & $+0.25 \pm 0.04$ & 9.9 \\
\hline \multicolumn{4}{|l|}{ Hawaii } \\
\hline Manuna Ulu $1974^{\mathrm{a}}$ & 118 & $+0.40 \pm 0.04$ & 8.1 \\
\hline KI79-3-150.4 ${ }^{\mathrm{c}}$ & 97 & $+0.27 \pm 0.04$ & 13.5 \\
\hline KIKI67-3-28 ${ }^{\mathrm{c}}$ & 104 & $+0.29 \pm 0.04$ & 12.0 \\
\hline IKI-58 ${ }^{\mathrm{c}}$ & 79 & $+0.27 \pm 0.04$ & 8.1 \\
\hline KI75-1-121.5 & 109 & $+0.30 \pm 0.04$ & 7.8 \\
\hline BHVO- $2^{\mathrm{d}}$ & 105 & $+0.33 \pm 0.05$ & 7.2 \\
\hline \multicolumn{4}{|l|}{ Iceland } \\
\hline $\mathrm{BIR} 1^{\mathrm{d}}$ & 74 & $+0.21 \pm 0.07$ & 9.7 \\
\hline \multicolumn{4}{|c|}{ Crozet $(6<\mathrm{MgO}<16 \mathrm{wt} \%)$ - this study } \\
\hline OVPG-8 & 109 & $+0.38 \pm 0.03$ & 7.2 \\
\hline OVPG-47 & 107 & $+0.36 \pm 0.02$ & 8.8 \\
\hline OVPG-48 & 96 & $+0.32 \pm 0.04$ & 8.8 \\
\hline OVPG-58 & 126 & $+0.35 \pm 0.02$ & 12.3 \\
\hline OVPG-13 & 86 & $+0.31 \pm 0.01$ & 12.3 \\
\hline \multicolumn{4}{|c|}{ Crozet $(\mathrm{MgO}<6$ and $>16 \mathrm{wt} \%)-$ this study } \\
\hline OVPG-1 & 118 & $+0.33 \pm 0.02$ & 4.1 \\
\hline OVPG-4 & 110 & $+0.38 \pm 0.02$ & 5.4 \\
\hline OVPG-16 & 112 & $+0.38 \pm 0.06$ & 5.9 \\
\hline OVPG-23 & 117 & $+0.31 \pm 0.02$ & 3.6 \\
\hline OVPG-28 & 116 & $+0.37 \pm 0.01$ & 5.7 \\
\hline OVPG-38 & 83 & $+0.32 \pm 0.03$ & 20.0 \\
\hline
\end{tabular}

Error is given as standard deviation (2SD). See Appendix 2 and 3 for the whole dataset and detailed results.

offset from JMC-Lyon by $+0.09 \pm 0.03 \%$ ( 2 SD, $n=200$ over 2 years of measurements). As such, $\mathrm{Zn}$ isotopic compositions are reported with the delta value in per mille notation $\left(\delta^{66} \mathrm{Zn}\right)$ relative to the JMC-Lyon using the conventional conversion equation from Hoefs (2018). Reference Zn solution IRMM-3702 was analyzed through each session giving a mean $\delta^{66} \mathrm{Zn}_{\text {IRMM-3702 of }}+0.28 \pm 0.04 \%$ (2SD, $\left.n=9\right)$ in good agreement with previous studies $(+0.29 \pm 0.04 \%$, http://georem. mpch-mainz.gwdg.de). External geostandards BHVO-2 and BCR-2 (basalts, USGS) were processed through chemistry and analyzed alongside samples. Total duplicates of sample OVPG-13 and OVPG-38 yielded standard deviation of \pm 0.01 and \pm 0.03 (2SD), respectively.

\subsection{Two-component melting-mixing model}

The composition of oceanic basalts was modeled considering mixing 
of partial melts from a ferile peridotite (spinel- or garnet-bearing) and recycled components (i.e., sediment, MORB-eclogite or C-bearing eclogite). The trace element composition of the residue $\left(C_{\text {residue }}\right)$ and melt $\left(C_{\text {melt }}\right)$ at a given degree of melt extraction $(\mathrm{F})$ is calculated using the accumulated fractional modal melting equations from Shaw (1970):

$C_{\text {residue }}=C_{0} *(1-F)^{1 / D_{0}-1}$

$C_{\text {melt }}=C_{0} *\left(1-(1-F)^{1 / D_{0}}\right) / F$

where $C_{0}$ and $D_{0}$ are the concentration and bulk partition coefficient of the trace element in the source, respectively. The bulk partition coefficient $D_{0}$ is function of the modal proportions $\left(X_{i}\right)$ and individual mineral-melt partition coefficients $\left(D_{i}^{\text {mineral }- \text { melt }}\right.$ or $\left.D_{i}\right)$ of the rock-forming minerals in the source $\left(D_{0}=\Sigma D_{i} * X_{i}\right)$. To model the range of stable isotope fractionation induced by partial melting in the residue $\left(\delta_{\text {residue }}\right)$ and melt $\left(\delta_{\text {melt }}\right)$, we use the Rayleigh distillation equations from Hoefs (2018):

$\delta_{\text {residue }}=\left(1000+\delta_{0}\right) * f^{(\alpha-1)}-1000$

$\delta_{\text {melt }}=\left(1000+\delta_{0}\right) *\left(1-f^{\alpha}\right) /(1-f)-1000$

where $\delta_{0}$ is the stable isotope composition of the source, $f$ is the remaining fraction of the element in the residue $\left(f=(1-F) * C_{\text {residue }} / C_{0}\right)$ and $\alpha$ is the isotopic fractionation factor between solid and melt. The isotopic fractionation factor $\alpha$ reflects the $\delta$ difference between the melt and the residue $\left(\Delta_{0}{ }^{\text {melt }- \text { residue }}=\delta_{\text {melt }}-\delta_{\text {residue }} \sim \ln (\alpha) * 1000\right)$, which is function of the modal proportions $\left(X_{i}\right)$ and individual mineral-melt $\Delta_{i}^{\text {mineral-melt }}$ of the rock-forming minerals in the source $\left(\Delta_{0}{ }^{\text {melt }- \text { residue }}=\Sigma \Delta_{i}^{\text {mineral-melt }} * X_{i}\right)$. Aggregate fractional melts from a fertile peridotite and recycled material are then mixed and the elemental $\left(C_{m i x}\right)$ and isotopic $\left(\delta_{m i x}\right)$ composition of the hybrid melt are given by the equations from DePaolo (1981):

$C_{\text {mix }}=X_{A} * C_{A}+X_{B} * C_{B}$

$\delta_{\text {mix }}=\delta_{A} * X_{A} * C_{A} / C_{\text {mix }}+\delta_{B} * X_{B} * C_{B} / C_{\text {mix }}$

where $X_{A, B}, C_{A, B}$ and $\delta_{A, B}$ are the proportion, concentration and isotope composition of melts $\mathrm{A}$ and $\mathrm{B}$, respectively. All modeling parameters are given in Table 3. Detailed results are provided in Appendix 4 and the composition of mixed melts from a fertile peridotite and sediments (brown curve and light brown field), MORB-eclogite (yellow curve) or C-bearing eclogite (black curve) sources are shown in Fig. 3-5. The C-bearing eclogite source is less constrained than sediments and MORB-eclogite. Hence, we also performed a melting-mixing Monte Carlo simulation accounting for the small but noteworthy compositional variability of C-bearing eclogites and the uncertainty on their estimated $\delta^{66} \mathrm{Zn}$ (see Appendix 4 and blue dots overlay in Fig. 3-5). Our melting-mixing model is a simplification of natural systems designed to evaluate the potential of $\mathrm{Zn}$ and $\mathrm{Zn}$ isotopes to trace recycled C-bearing material in the mantle source of oceanic basalts. Re-melting of metasomatized peridotites and hybrid pyroxenites formed by reaction between eclogite-derived melts and ambient peridotite has also been proposed to explain the compositional heterogeneity of oceanic basalts (Herzberg, 2006; Sobolev et al., 2005, 2007). However, hybridization processes and the resulting mineralogy of the refertilized mantle remain unconstrained at that time (e.g., Mallik and Dasgupta, 2012). Our study does not exclude such melt-rock reactions but a more elaborate investigation of their role on $\mathrm{Zn}$ heterogeneity in oceanic basalts would be highly speculative, limiting their consideration in the present model.

\section{Discussion}

\subsection{Zinc behavior during igneous differentiation and subduction processes}

A primary implicit assumption for the use of $\mathrm{Zn}$ and $\mathrm{Zn}$ isotopes as tracers of recycled material and deep carbon cycling in the mantle is that they suffer little or no fractionation during igneous and subduction processes. The composition of oceanic basalts, however, may vary considerably during magmatic differentiation and no longer truly reflect the signature of their mantle sources (e.g., Teng et al., 2008; Williams et al., 2009 for Fe; Savage et al., 2011 for Si). Fractionation of fluid-mobile elements and their stable isotopes can also be significant during prograde metamorphism and dehydration accompanying subduction (e.g., Zack et al., 2003 for Li; Debret et al., 2016, 2018a for Fe). Therefore, the magnitude of $\mathrm{Zn}$ and $\delta^{66} \mathrm{Zn}$ fractionation induced by (1) partial melting, (2) subsequent fractional crystallization and (3) subduction zone metamorphism must first be addressed.

\subsubsection{Partial melting}

In contrast to REE and other highly incompatible trace elements, most FRTEs have a $D_{i}^{\text {mineral-melt }}$ close to unity in olivine (Ol) and orthopyroxene $(\mathrm{Opx})$, the two most abundant minerals in peridotites (Table 1, Le Roux et al., 2011; Davis et al., 2013; Mallmann and O'Neill, 2009). As such, FRTEs have a bulk partition coefficient $D_{0}{ }^{\text {source-melt }} \sim 1$ and remain relatively unfractionated during partial melting of a peridotite source $\left(C_{\text {residue }} \sim C_{\text {melt }} \sim C_{\text {source }}\right)$. Interestingly, some FRTEs exhibit more variable $D_{i}^{\text {mineral - melt }}$ in clinopyroxene (Cpx) and/or garnet (Gt, Le Roux et al., 2011). Therefore, eclogite and peridotite derived melts will have distinct FRTEs signatures, which has been used to trace mineralogical heterogeneities in the mantle (see Yang et al., 2016 and references therein). However, element partitioning is not solely controlled by the modal mineralogy of the source rock but varies by orders of magnitude with changes in temperature $(\mathrm{T})$, pressure $(\mathrm{P})$, melt composition and/or redox conditions (Blundy and Wood, 2003; Wood and Blundy, 2002; O'Neill and Eggins, 2002). Among the FRTEs, Zn is a lithophile element with a single valence state $\left(\mathrm{Zn}^{2+}\right)$ at upper mantle conditions. Sulfides are known to be ubiquitous accessory phases in the silicate mantle, and $\mathrm{Zn}$ may also behave as a chalcophile element (average $D_{Z n}^{\text {sulfide-silicate }} \sim 3.5 \pm 0.85$, Patten et al., 2013; Wood and Kiseeva, 2015). Yet, contribution of sulfides to the bulk $D_{Z n}$ source-melt during mantle melting is negligible $(\sim 0.002 \%$ assuming a weight fraction of $5.10^{-4} \%$ of sulfides, Patten et al., 2013). Because the $\mathrm{Zn} / \mathrm{Fe}$ ratio remains relatively unaffected by metasomatic processes and its partitioning appears to be even more P-T independent, Le Roux et al. (2015) further advocate for the use of this geochemical proxy rather than simply $\mathrm{Zn}$ systematics. $\mathrm{Zn} / \mathrm{Fe}$ is also redox-sensitive (i.e., $\mathrm{Fe}^{3+}$ is more incompatible than $\mathrm{Fe}^{2+}$ and $\mathrm{Zn}^{2+}$, Lee et al., 2010), but any oxygen fugacity $\left(\mathrm{fO}_{2}\right)$ dependency can be ruled out for MORB and OIB given that they have similar oxidation state (Frost and McCammon, 2008). As a result, Zn/Fe ratios in oceanic basalts are likely to carry the signature of the mineralogy of their sources (i.e. peridotite vs eclogite) irrespective of the presence of accessory sulfides, $f_{2}$ and P-T conditions during the onset of melting and percolation of hydrous fluids and melts (Le Roux et al., 2010, 2011, 2015).

In terms of $\mathrm{Zn}$ stable isotopes, equilibrium fractionation decreases proportionally to $1 / \mathrm{T}^{2}$ (Urey, 1947; Schauble, 2004). Consequently, and considering that $\mathrm{Zn}$ is barely fractionated during mantle melting (i.e., $C_{\text {residue }} \sim C_{\text {melt }} \sim C_{\text {source }}$ ), Sossi et al. (2018) argued that $\delta^{66} \mathrm{Zn}$ enrichment in primary basaltic melts should not exceed $+0.08 \%$ relative to their sources. Mass balance implies minimal $\mathrm{Zn}$ isotope variations in the residual peridotite counterpart (up to $0.0015 \%$ after $30 \%$ partial melting, Sossi et al., 2018). This result is in good agreement with the tight range of $\delta^{66} \mathrm{Zn}$ in unaltered mantle peridotites (average $\delta^{66} \mathrm{Zn}=+0.18 \pm 0.06 \%$, Sossi et al., 2018; Doucet et al., 2016; Wang et al., 2017; Huang et al., 2018b). Incorporation of any isotopically offset component in the mantle (i.e., $\Delta^{66} \mathrm{Zn}_{\text {exotic compo- }}$ nent-mantle $>>0.08 \%$ ) is thus expected to generate larger $\delta^{66} \mathrm{Zn}$ anomalies in oceanic basalts than melting processes. In turn, $\delta^{66} \mathrm{Zn}$ variations in MORB and OIB -if any - may be used to track the presence of isotopically light or heavy recycled material in their sources.

\subsubsection{Fractional crystallization}

Olivine is the primary host of $\mathrm{Zn}$ among silicates cristallising from 
Table 3

Mineral modes (\%), recommended $\mathrm{Zn}$, Fe and $\mathrm{Zn} / \mathrm{Fe}$ partition coefficients (D) and $\mathrm{Zn}$ isotope fractionation factors ( $\Delta^{66} \mathrm{Zn}$, \%o) suitable for mantle melting.

\begin{tabular}{|c|c|c|c|c|c|}
\hline Source & Mode (\%) & $\mathrm{D}_{\mathrm{Zn}}$ & $\mathrm{D}_{\mathrm{Fe}}$ & $\mathrm{D}_{\mathrm{Zn} / \mathrm{Fe}}$ & $\Delta_{\mathrm{Zn}}^{66}(\% 0)$ \\
\hline \multicolumn{6}{|c|}{ Sp-peridotite } \\
\hline $\mathrm{Ol}$ & 53.5 & $0.99 \pm 0.14$ & $1.06 \pm 0.05$ & $0.93 \pm 0.14$ & $-0.17 \times 10^{6} / \mathrm{T}^{2}$ \\
\hline Opx & 26.0 & $0.68 \pm 0.07$ & $0.69 \pm 0.05$ & $0.99 \pm 0.12$ & $-0.17 \times 10^{6} / \mathrm{T}^{2}$ \\
\hline Cpx & 18.5 & $0.48 \pm 0.00$ & $0.71 \pm 0.04$ & $0.68 \pm 0.04$ & $-0.17 \times 10^{6} / \mathrm{T}^{2}$ \\
\hline Sp & 2.0 & $5.20 \pm 0.05$ & $3.00 \pm 0.06$ & $5.47 \pm 0.35$ & $0.00 \times 10^{6} / \mathrm{T}^{2}$ \\
\hline Bulk & 100 & 0.90 & 0.90 & 0.99 & $-0.17 \times 10^{6} / \mathrm{T}^{2}$ \\
\hline \multicolumn{6}{|c|}{ Gt-Peridotite } \\
\hline $\mathrm{Ol}$ & 53 & $0.96 \pm 0.04$ & $1.03 \pm 0.16$ & $0.93 \pm 0.15$ & $-0.17 \times 10^{6} / \mathrm{T}^{2}$ \\
\hline Opx & 18 & $0.45 \pm 0.17$ & $0.55 \pm 0.01$ & $0.82 \pm 0.31$ & $-0.17 \times 10^{6} / \mathrm{T}^{2}$ \\
\hline Cpx & 27 & $0.33 \pm 0.17$ & $0.49 \pm 0.01$ & $0.68 \pm 0.35$ & $-0.17 \times 10^{6} / \mathrm{T}^{2}$ \\
\hline Gt & 2 & $0.21 \pm 0.09$ & $0.65 \pm 0.07$ & $0.33 \pm 0.14$ & $-0.20 \times 10^{6} / \mathrm{T}^{2}$ \\
\hline Bulk & 100 & 0.68 & 0.79 & 0.83 & $-0.17 \times 10^{6} / \mathrm{T}^{2}$ \\
\hline \multicolumn{6}{|c|}{ MORB-eclogite (low-Gt) } \\
\hline Cpx & 75 & $0.68 \pm 0.05$ & $0.94 \pm 0.05$ & $0.72 \pm 0.07$ & $-0.17 \times 10^{6} / \mathrm{T}^{2}$ \\
\hline Gt & 25 & $0.89 \pm 0.11$ & $2.50 \pm 0.03$ & $0.36 \pm 0.04$ & $-0.20 \times 10^{6} / \mathrm{T}^{2}$ \\
\hline Bulk & 100 & 0.73 & 1.32 & 0.63 & $-0.18 \times 10^{6} / \mathrm{T}^{2}$ \\
\hline \multicolumn{6}{|c|}{ MORB-eclogite (high-Gt) } \\
\hline Cpx & 60 & $0.68 \pm 0.05$ & $0.94 \pm 0.05$ & $0.72 \pm 0.07$ & $-0.17 \times 10^{6} / \mathrm{T}^{2}$ \\
\hline Gt & 40 & $0.89 \pm 0.11$ & $2.50 \pm 0.03$ & $0.36 \pm 0.04$ & $-0.20 \times 10^{6} / \mathrm{T}^{2}$ \\
\hline Bulk & 100 & 0.76 & 1.55 & 0.49 & $-0.18 \times 10^{6} / \mathrm{T}^{2}$ \\
\hline \multicolumn{6}{|c|}{ C-bearing eclogite } \\
\hline Cpx & 60 & $0.68 \pm 0.05$ & $0.94 \pm 0.05$ & $0.72 \pm 0.07$ & $-0.17 \times 10^{6} / \mathrm{T}^{2}$ \\
\hline Gt & 35 & $0.89 \pm 0.11$ & $2.50 \pm 0.03$ & $0.36 \pm 0.04$ & $-0.20 \times 10^{6} / \mathrm{T}^{2}$ \\
\hline Carb & 5 & $0.23 \pm 0.00$ & $0.36 \pm 0.00$ & $0.64 \pm 0.00$ & $0.16 \times 10^{6} / \mathrm{T}^{2}$ \\
\hline Bulk & 100 & 0.73 & 1.44 & 0.51 & $-0.16 \times 10^{6} / \mathrm{T}^{2}$ \\
\hline \multicolumn{6}{|c|}{ Sediments } \\
\hline Bulk & - & 0.84 & 0.77 & 1.09 & - \\
\hline
\end{tabular}

Mineral modes are from Wasylenki (2003) and Walter (1998) for peridotite, Pertermann (2003) and Urann et al. (2020) for MORB-eclogite, Ravna et al. (2017) for Cbearing eclogite and Grassi et al. (2012) for sediments. Partition coefficients are from the compilation of Le Roux et al. (2015) except carbonate partition coefficients from Sweeney et al. (1995). Zn isotope fractionation factors are from Sossi et al. (2018) and McCoy-West et al. (2018) except carbonates for which we used ab initio calculated fractionation factors between anhydrous carbonate $\left(\mathrm{ZnCO}_{3}\right)$ and spinel $\left(\mathrm{ZnAl}_{2} \mathrm{O}_{4}\right.$, values from Ducher et al., 2016). A temperature of $1573 \mathrm{~K}$ is assumed in our melting models.

basaltic magmas (Doe, 1995; Le Roux et al., 2010). Given that $D_{Z n}{ }^{\text {ol-melt }}$ and $D_{Z n / F e} e^{o l-m e l t}$ are both close to one, olivine crystallization or accumulation has minimal effect on the $\mathrm{Zn}$ and $\mathrm{Zn} / \mathrm{Fe}$ composition of basaltic melts. However, $\mathrm{Zn}$ is more incompatible in other silicates, especially in clinopyroxene $\left(D_{Z n}{ }^{c p x-m e l t} \sim 0.3-0.7\right.$, Le Roux et al., 2015) and plagioclase $\left(D_{Z n}{ }^{p l-m e l t} \sim 0.2\right.$, Ewart and Griffin, 1994). Because these two phases appear on the cotectic at $\sim 8 \mathrm{wt} \% \mathrm{MgO}$ (Jenner and O'Neill, 2012), the Zn content and $\mathrm{Zn} / \mathrm{Fe}$ ratio of basaltic melts are expected to increase drastically in more differentiated magmas. This assumption is readily assessed in the example of Icelandic basalts provided in Supplementary Fig. 1a, b. Samples display a clear trend of increasing $\mathrm{Zn}$ and $\mathrm{Zn} / \mathrm{Fe}$ with falling $\mathrm{MgO}$, from $\sim 75 \mathrm{ppm}$ of $\mathrm{Zn}$ and $\mathrm{Zn} / \mathrm{Fe}$ of $\sim 9.5 \times 10^{4}$ at $\mathrm{MgO} \sim 10-15 \mathrm{wt} \%$ to $\sim 175 \mathrm{ppm}$ of $\mathrm{Zn}$ and $\mathrm{Zn} /$ Fe of $\sim 15 \times 10^{4}$ at $\mathrm{MgO} \sim 5 \mathrm{wt} \%$. These observations highlight the importance of our filtering scheme to study the most primary melts ( $9 \mathrm{wt} \%<\mathrm{MgO}<16 \mathrm{wt} \%$ ) for tracing mantle heterogeneities.

Based on suites of cogenetic samples, Chen et al. (2013) showed that fractional crystallization of isotopically light olivine $\left(\delta^{66} \mathrm{Zn}\right.$ up to $-0.30 \pm 0.02 \%$, McCoy-West et al., 2018) \pm Fe-Ti oxides might induce a $\mathrm{Zn}$ isotopic shift up to $\sim 0.10 \%$ with increasing degree of differentiation. Namely, $\delta^{66} \mathrm{Zn}$ in samples from Kilauea Iki lava lake (Hawaii) range from $+0.29 \pm 0.04 \%$ in near-primary basalts $(12.0 \mathrm{wt}$ $\% \mathrm{MgO}$ ) to $+0.36 \pm 0.04 \%$ in more compositionally-evolved melts (2.4 wt $\% \mathrm{MgO}$, Chen et al., 2013). Conversely, $\delta^{66} \mathrm{Zn}$ values as low as $+0.18 \pm 0.00 \%$ and $+0.04 \pm 0.01 \%$ in high-MgO picrites and cumulate komatiites have been attributed to accumulation of isotopically light olivines (McCoy-West et al., 2018; Sossi et al., 2018). For basaltic samples with $6 \mathrm{wt} \%<\mathrm{MgO}<16 \mathrm{wt} \%$, however, there is no correlation between $\mathrm{Zn}$ isotope composition and degree of differentiation within analytical uncertainty. The data reported for basanites and picrites from the Crozet archipelago in this study further confirm these observations (Supplementary Fig. 2). Hence, $\delta^{66} \mathrm{Zn}$ systematics in nearprimary melts can be used to trace recycled material in their mantle sources.

\subsubsection{Subduction zone metamorphism}

Zinc isotopes can be significantly fractionated during fluid-rock interactions (Debret et al., 2018b). Pons et al. (2016) reported a progressive decrease of $\delta^{66} \mathrm{Zn}$ in subducted serpentinites with increasing metamorphic grade and degree of dehydration, from greenschist $\left(\delta^{66} \mathrm{Zn}=+0.32 \pm 0.08 \%\right.$ ) to eclogite $\left(\delta^{66} \mathrm{Zn}=+0.16 \pm 0.06 \% 0\right) \mathrm{P}$ $\mathrm{T}$ facies conditions. Similarly, Debret et al. (2018a) showed the existence of abnormally low $\delta^{66} \mathrm{Zn}$ in decarbonated serpentinites $\left(\delta^{66} \mathrm{Zn}\right.$ down to $-0.56 \pm 0.02 \%$ ) relative to C-bearing serpentinites $\left(\delta^{66} \mathrm{Zn}=+0.21-0.05 \%\right)$ from blueschist terrains. Both observations clearly point towards the release of isotopically heavy- $\delta^{66} \mathrm{Zn}, \mathrm{S}$ - and Cbearing dehydration fluids during serpentine breakdown and decarbonation of the serpentinized slab mantle. However, it remains an active research topic to determine (1) whether Zn-bearing fluids are released at discrete metasomatic interfaces or broader portions of the slab serpentinites; and (2) whether these fluids are sufficiently concentrated in $\mathrm{Zn}$ to deeply influence the signature of the dehydrated slab (and/or that of the sub-arc mantle).

In constrast with serpentinites, no systematic $\mathrm{Zn}$ isotope fractionation has been reported in the mafic lithologies of the subducted slab, irrespective of their metamorphic facies (i.e., from greenschist to eclogite P-T conditions) and/or indicators of fluid-rock interaction (Inglis et al., 2017; Xu and Liu, 2018). Rather, the $\delta^{66} \mathrm{Zn}$ signature of basaltic eclogites $\left(\delta^{66} \mathrm{Zn}=+0.27 \pm 0.08 \%\right.$, Inglis et al., 2017) overlaps with their inferred MORB $\left(\delta^{66} \mathrm{Zn}_{\text {MORB }}=+0.27 \pm 0.05 \%\right.$, Huang et al., 2018a; Wang et al., 2017) or Altered Oceanic Crust $\left(\delta^{66} \mathrm{Zn}_{\mathrm{AOC}}=+0.27 \pm 0.01 \%\right.$, Huang et al., 2016) protolith. 

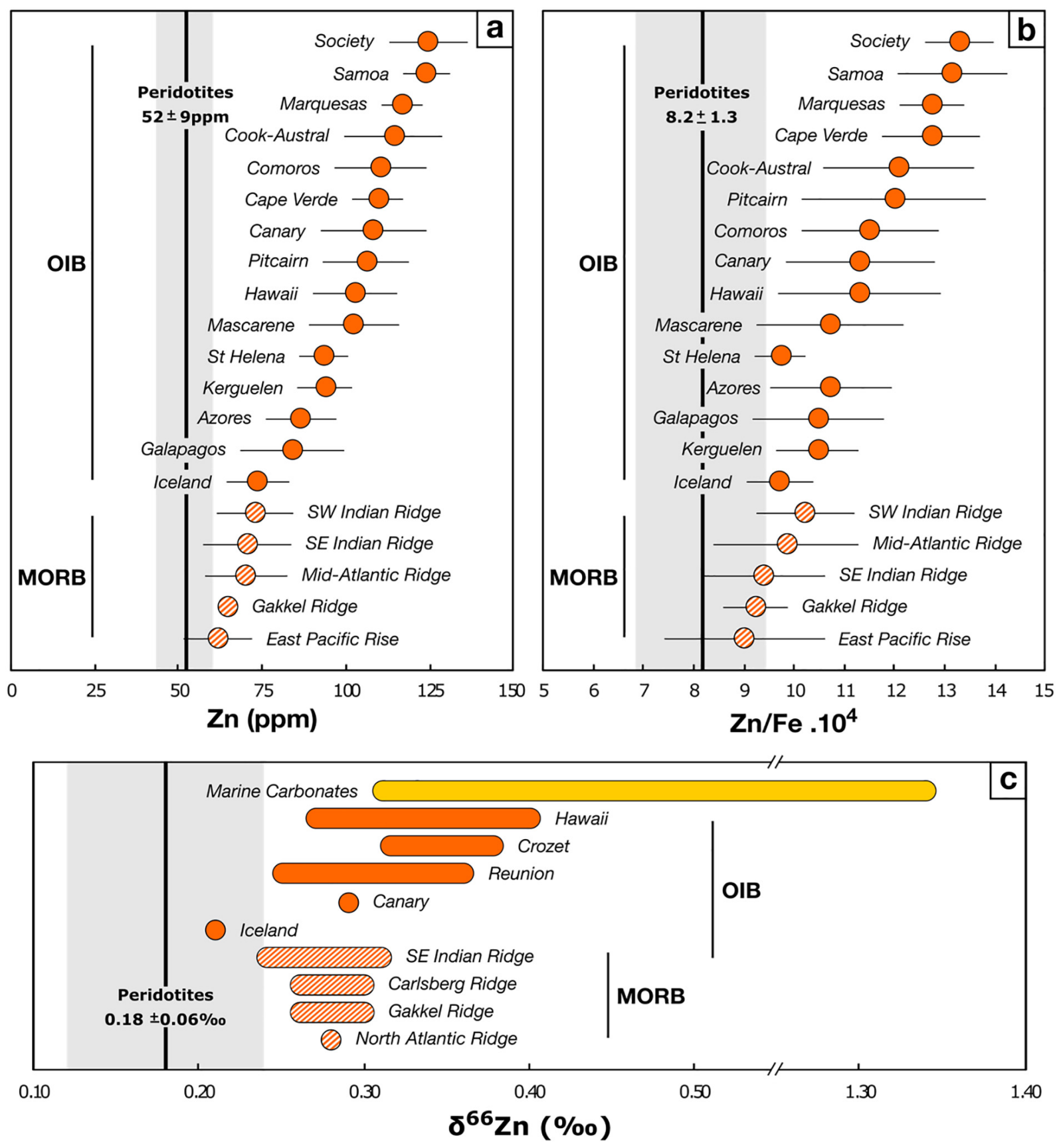

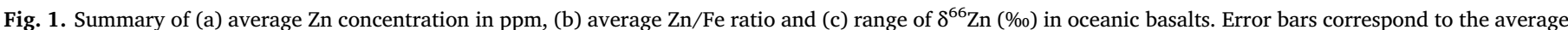




Wang et al., 2017; Huang et al., 2018a; Chen et al., 2013, the GEOREM database (http://georem.mpch-mainz.gwdg.de) and this study.

Continental margin sediments and subducted metasediments also display similar, although more variable, range of $\delta^{66} \mathrm{Zn}$ compositionwith an average of $+0.07 \pm 0.11 \%$ and $+0.06 \pm 0.19 \%$, respectively (Little et al., 2016; Inglis et al., 2017). Collectively, this suggests that relatively small amounts of $\mathrm{Zn}$ are mobilized from the subducted mafic oceanic crust and associated metasediments in S- or C-bearing dehydration fluids suring subduction zones. Most importantly, crustal and meta-sedimentary materials may retain, at least partly, their abyssal $\mathrm{Zn}$ isotope signature during subduction. Given the strong affinity of isotopically heavy $\mathrm{Zn}$ for either reduced or oxidized C-bearing material (Ducher et al., 2016; Fujii et al., 2011; Black et al., 2011), it seems therefore reasonable to consider the recycling of a C-bearing eclogite crust with a heavy $\delta^{66} \mathrm{Zn}$ signature in our models.

\subsection{Zinc inventory of oceanic basalts}

Zinc content of oceanic basalts originating from ridges, plumes or plume-ridge interaction differs according to their tectonic settings (Table 1 and Fig. 1a-c). MORB display the lowest $\mathrm{Zn}$ contents $(68 \pm 12 \mathrm{ppm}$, all MORB average) and $\mathrm{Zn} / \mathrm{Fe}$ ratios $\left(9.6 \pm 1.5 \times 10^{4}\right)$, only slightly higher than average mantle peridotites $\left(\mathrm{Zn}=52 \pm 9 \mathrm{ppm} ; \mathrm{Zn} / \mathrm{Fe}=8.2 \pm 1.3 \times 10^{4}\right)$. Using recommended mineral-melt partition coefficients (Le Roux et al., 2015) and mineralogy estimates of the primitive mantle (Table 3, Wasylenki, 2003; Walter, 1998), we find a bulk $D_{Z n}$ peridotite-melt of $0.68-0.90$ and $D_{Z n}$ peridotite-melt of $0.83-0.99$ for melting of a spinel- or garnet-bearing peridotite. As the melting degree $(\mathrm{F})$ tends towards zero, the maximum 
$\mathrm{Zn}$ concentration and $\mathrm{Zn} / \mathrm{Fe}$ ratio induced by melting of a primitive mantle source $\left(\mathrm{Zn}_{\mathrm{PM}}=53.5 \mathrm{ppm}\right.$ and $\mathrm{Zn} / \mathrm{Fe}_{\mathrm{PM}}=8.5 \times 10^{4}$, Palme and O'Neill, 2007) should not exceed $78 \mathrm{ppm}$ and $9.8 \times 10^{4}$, respectively (Eq. (2)). This result is perfectly in line with the full range of $\mathrm{Zn}$ $(62 \pm 10$ to $73 \pm 11 \mathrm{ppm})$ and $\mathrm{Zn} / \mathrm{Fe}(9.0 \pm 1.6$ to $10.2 \pm 1.0 \times 10^{4}$ ) observed in basalts erupted at mid-ocean ridges. MORB also have homogeneous and slightly heavier $\delta^{66} \mathrm{Zn}$ values $(+0.24 \pm 0.01$ to $+0.31 \pm 0.02 \% 0)$ relative to average unmetasomatized peridotites $(+0.18 \pm 0.06 \%)$. Based on individual $\Delta_{i}^{\text {mineral-melt }}$ (Table 3, Sossi et al., 2018; McCoy-West et al., 2018) and primitive mantle estimates $\left(\delta^{66} \mathrm{Zn}_{\mathrm{PM}}=+0.16 \pm 0.06 \%\right.$, Sossi et al., 2018), a maximum $\delta^{66} \mathrm{Zn}$ of $+0.23 \%$ is modeled in the peridotite melt (Eq. (4)). This result is in reasonably good agreement with the average $\delta^{66} \mathrm{Zn}$ of all MORB $(+0.28 \pm 0.04 \%$ ).

In contrast, OIB exhibit more variability than MORB and mantle peridotites (Table 1 and Fig. $1 \mathrm{a}-\mathrm{c}$ ). $\mathrm{Zn}, \mathrm{Zn} / \mathrm{Fe}$ and $\delta^{66} \mathrm{Zn}$ increase from OIB suites near or on active ridges $(\mathrm{Zn}=74 \pm 9$ to $94 \pm 8 \mathrm{ppm}, \mathrm{Zn} /$ $\mathrm{Fe}=9.7 \pm 0.7$ to $10.5 \pm 0.8 \times 10^{4}, \delta^{66} \mathrm{Zn}=+0.21 \pm 0.07 \% 0$ ) to OIB far from ridges $(\mathrm{Zn}=93 \pm 7$ to $124 \pm 7 \mathrm{ppm}, \mathrm{Zn} / \mathrm{Fe}=9.7 \pm$ 0.5 to $13.3 \pm 0.7 \times 10^{4}, \delta^{66} \mathrm{Zn}=+0.25 \pm 0.04$ to $+0.40 \pm 0.04 \%$ ). This observation reflects the well-known plumeridge interactions of Schilling et al. (1983) nicely illustrated in the example of MORB from the SWIR provided in Fig. 2. In any case, both $\mathrm{Zn}$ elemental and isotopic compositions of OIB are irreconcilable with partial melting of a primitive mantle source only, suggesting the participation of an additional component.

Another striking feature is the global correlation between $\mathrm{Zn}$ abundance and $\mathrm{Sr}-\mathrm{Nd}$ radiogenic isotopes in MORB, MORB-related OIB and OIB far from ridges (Fig. 3a, b). Such complementary results are not surprising given the global correlation between ${ }^{87 / 86} \mathrm{Sr}$ and ${ }^{143 / 144} \mathrm{Nd}$ in oceanic basalts (e.g., Hofmann, 1997 and references therein). This crucial observation, however, clearly points towards a $\mathrm{Zn}$ enrichment in OIB inherited from the source rather than melting processes. Unfortunately, the relationship between $\delta^{66} \mathrm{Zn}$ and Sr-Nd isotopes in basalts from our compilation cannot be investigated due to the lack of


Fig. 2. Longitude $\left({ }^{\circ}\right)$ vs (a) latitude $\left({ }^{\circ}\right)$ and (b) Zn concentration (ppm) in nearprimary basalts from the Southweast Indian Ridge (SWIR) illustrating the effect of plume-ridge interaction on the $\mathrm{Zn}$ composition of oceanic basalts. The map in (a) was prepared using GeoMapApp (http://www.geomapapp.org). Coordinates for the Bouvet hotspot are from Courtillot et al. (2003).
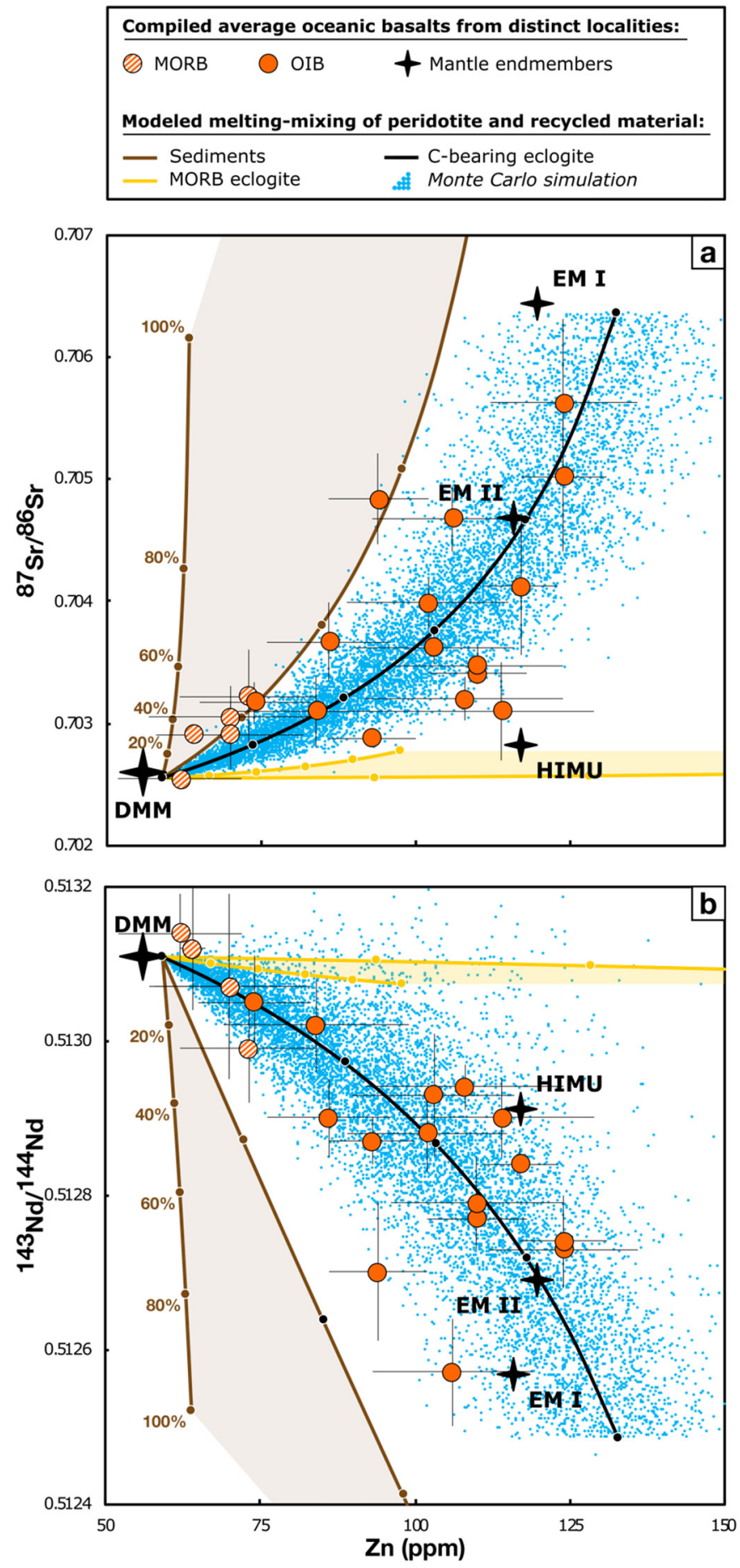

Fig. 3. Average $\mathrm{Zn}$ concentration (ppm) vs (a) ${ }^{87 / 86} \mathrm{Sr}$ and (b) ${ }^{143 / 144} \mathrm{Nd}$ in oceanic basalts. Also shown are mixing curves between peridotite and sediments (brown curves and light brown field), MORB-eclogite (yellow curves and light yellow field) and C-bearing eclogite (black curve and blue dots overlay for the Monte Carlo simulation). Depleted-MORB Mantle (DMM) estimates from Salters and Stracke (2004) and EM I, EM II and HIMU end-members calculated from our compilation and following the method of Jackson and Dasgupta (2008). See Table 1 and Appendix 1 for the whole dataset and references and Appendix 4 for modeling results. (For interpretation of the references to color in this figure legend, the reader is referred to the web version of this article.)

available data and calls for further investigations. All of these observations indicate that the putative recycled component(s) in the source of OIB must display (1) high $\mathrm{Zn}$ content and $\mathrm{Zn} / \mathrm{Fe}$ ratio, (2) 
isotopically heavy $\delta^{66} \mathrm{Zn}$ signature and (3) relatively radiogenic ${ }^{87 / 86} \mathrm{Sr}$ and unradiogenic ${ }^{143 / 144} \mathrm{Nd}$ signatures relative to the terrestrial mantle. In the following sections, we investigate the effect of addition of recycled subducted material (i.e., sediment, MORB-eclogite and Cbearing eclogite) on the $\mathrm{Zn}$ composition of oceanic basalt.

\subsection{MORB-type oceanic crust recycling}

Based on the lower $D_{Z n / F e}$ mineral-melt of clinopyroxene and garnet relative to olivine and orthopyroxene (Table 3), Le Roux et al., 2015 argued that the high $\mathrm{Zn} / \mathrm{Fe}$ recorded in OIB derive from melting of MORB-eclogites or garnet pyroxenites (i.e. olivine-free, clinopyroxeneand garnet-bearing lithologies). Accounting for the variability in modal proportions of natural MORB-eclogites $(75 \% \mathrm{Cpx}+25 \% \mathrm{Gt}$, Pertermann and Hirschmann, 2003; 60\%Cpx $+40 \%$ Gt, Urann et al., 2020) and relevant mineral-melt partition coefficients (Table 3, Le Roux et al., 2015), MORB-eclogites have a bulk $D_{Z n}{ }^{\text {MORBecl-melt }}$ and $D_{Z n /}$ ${ }_{F e}{ }^{\text {MORBecl-melt }}$ of 0.73-0.76 and 0.49-0.63, respectively. Eclogites have a higher melt productivity and a lower solidus than dry peridotites (Kogiso, 2004; Leitch and Davies, 2001). Hence, if present in the source of OIB, they are expected to be about $60 \%$ molten for incipient melting (here $\mathrm{F}=1 \%$ ) of the surrounding peridotite mantle (Pertermann and Hirschmann, 2003). According to Eq. (2), melting of MORB-like eclogite (average $\mathrm{Zn}=82 \mathrm{ppm}$ and $\mathrm{Zn} / \mathrm{Fe}=9.4 \times 104$ for low-Gt MORBeclogite, Inglis et al., 2017; average $\mathrm{Zn}=198 \mathrm{ppm}$ and $\mathrm{Zn} /$ $\mathrm{Fe}=20.2 \times 104$ for high-Gt MORB-eclogite, John et al., 2010) will generate partial melts with $98-231 \mathrm{ppm}$ of $\mathrm{Zn}$ and $\mathrm{Zn} / \mathrm{Fe}$ of $13.4-31.6 \times 10^{4}$ after $60 \%$ melt extraction. Zinc concentrations and $\mathrm{Zn} / \mathrm{Fe}$ ratios of modeled peridotite and MORB-eclogite derived melts (after 1 and 60\% melting, respectively) thus encompass the entire range of OIB in good agreement with Le Roux et al. (2015). However, in a Zn vs $\mathrm{Zn} / \mathrm{Fe}$ plot, the mixing curves between peridotite and low- or high-Gt MORB-eclogite melts are offset from the global trend of oceanic basalts (Fig. 4, yellow curves), predicting too high $\mathrm{Zn} / \mathrm{Fe}$ ratios at a given $\mathrm{Zn}$ content. $\mathrm{Zn} / \mathrm{Fe}$ positively correlates with $\mathrm{Zn}$ abundances of oceanic basalts $\left(\mathrm{R}^{2}=0.87\right.$, MORB and OIB) but not with their $\mathrm{FeO}^{\mathrm{T}}$ content $\left(R^{2}=0.48\right)$. Hence, the higher $\mathrm{Zn} / \mathrm{Fe}$ observed in OIB compared to MORB is linked to $\mathrm{Zn}$ enrichment rather than Fe depletion. However, the lower bulk $D_{Z n / F e}$ source-melt of MORB-eclogite relative to fertile peridotite (0.49-0.63 and $0.83-0.99$, respectively) actually derives from distinct bulk Fe exchange coefficients $\left(D_{F e} e^{\text {MORBect-melt }}=1.32-1.55\right.$ and $D_{F e}^{\text {peridotite-melt }}=0.79-0.90$ ) rather than bulk $\mathrm{Zn}$ partitioning $\left(D_{Z n}{ }^{\text {MORBecl-melt }}=0.73-0.76\right.$ and $D_{Z n}{ }^{\text {peridotite }- \text { melt }}=0.68-0.90$, see Table 3). While the two independent observations that (1) $\mathrm{Zn} / \mathrm{Fe}$ varies in oceanic basalts and (2) $D_{Z n / F e}{ }^{\text {source-melt }}$ differs between peridotite and MORB-eclogite are perfectly accurate, they cannot be linked - a conclusion further supported by the global trend between $\mathrm{Zn}$ enrichment and radiogenic $\mathrm{Sr}$-Nd isotope composition observed in oceanic basalts. We emphasize that all pyroxenites with composition spanning from peridotite to MORB-eclogite can also be ruled out as the source of $\mathrm{Zn}$ enrichment in OIB.

We also modeled the range of $\delta^{66} \mathrm{Zn},{ }^{87 / 86} \mathrm{Sr}$ and ${ }^{143 / 144} \mathrm{Nd}$ generated by melting-mixing of a fertile peridotite $\left(\delta^{66} \mathrm{Zn}=+0.16 \pm 0.06 \% 0, \mathrm{Sr}=22 \mathrm{ppm}, \mathrm{Nd}=1.34 \mathrm{ppm},{ }^{87} /\right.$ ${ }^{86} \mathrm{Sr}=0.70260$ and ${ }^{143 / 144} \mathrm{Nd}=0.51311$, Sossi et al., 2018; Palme and O'Neill, 2007; Salters and Stracke, 2004) and MORB-eclogite (average $\delta^{66} \mathrm{Zn}=+0.27 \pm 0.08 \% 0, \mathrm{Sr}=64-216 \mathrm{ppm}, \mathrm{Nd}=13-23 \mathrm{ppm},{ }^{87 /}$ ${ }^{86} \mathrm{Sr}=0.70282$ and ${ }^{143 / 144} \mathrm{Nd}=0.51307$, Gale et al., 2013; Inglis et al., 2017; John et al., 2010) sources. Resulting mixing curves are systematically offset from the oceanic basalt array (Figs. 3a, b and 5, yellow curves). Neither peridotite melt $\left(\delta^{66} \mathrm{Zn}=+0.23 \%\right.$, 87 / ${ }^{86} \mathrm{Sr}=0.70260$ and ${ }^{143 / 144} \mathrm{Nd}=0.51311$ ) nor MORB-eclogite melt $\left(\delta^{66} \mathrm{Zn}=+0.26-+0.27 \%,{ }^{87 / 86} \mathrm{Sr}=0.70282\right.$ and ${ }^{143}$ / $\left.{ }^{144} \mathrm{Nd}=0.51307\right)$ can produce the heavy $\delta^{66} \mathrm{Zn}$ and $\mathrm{Sr}$-Nd isotope composition associated to the high $\mathrm{Zn}$ content of OIB (up to $\delta^{66} \mathrm{Zn}=+0.40 \%,{ }^{87 / 86} \mathrm{Sr}=0.70562$ and $\left.{ }^{143 / 144} \mathrm{Nd}=0.51257\right)$.
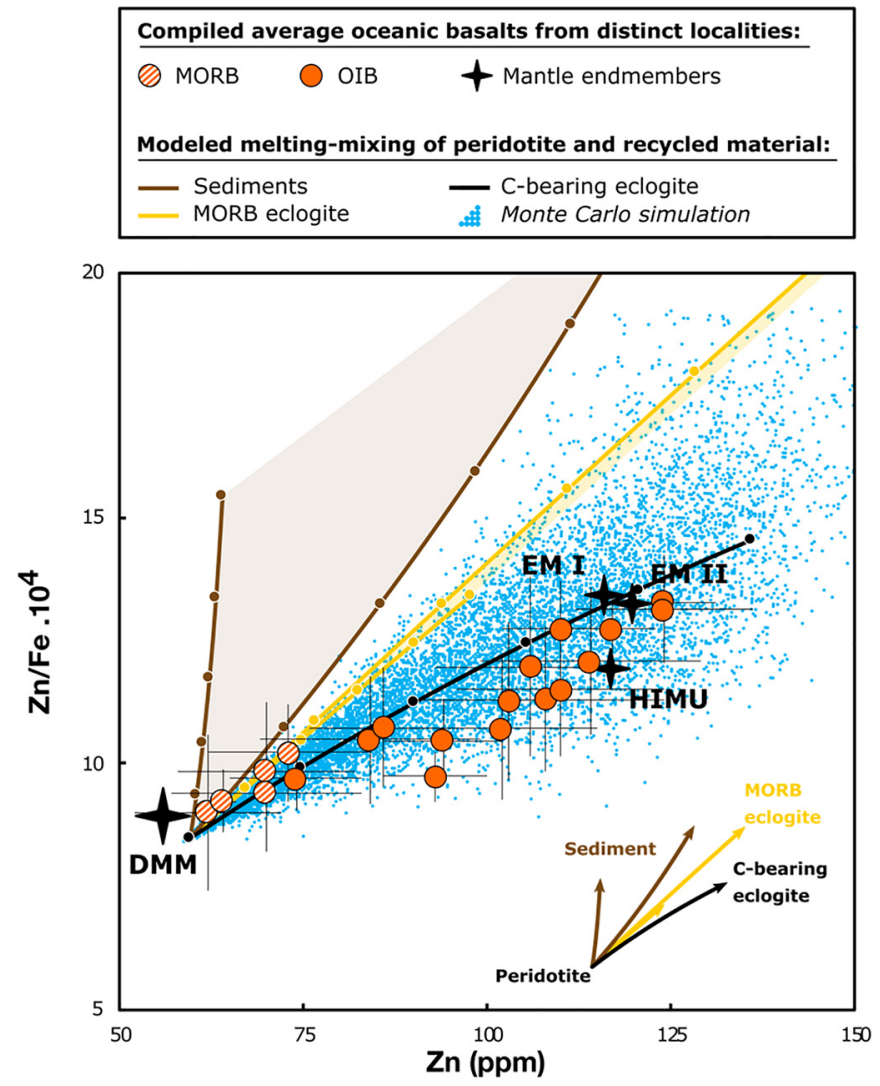

Fig. 4. Average $\mathrm{Zn}$ concentration (ppm) vs $\mathrm{Zn} / \mathrm{Fe}$ ratio in oceanic basalts. Also shown are mixing curves between peridotite and sediments (brown curves and light brown field), MORB-eclogite (yellow curves and light yellow field) and Cbearing eclogite (black curve and blue dots overlay for the Monte Carlo simulation). Depleted-MORB Mantle (DMM) estimates from Salters and Stracke (2004) and EM I, EM II and HIMU end-members calculated from our compilation and following the method of Jackson and Dasgupta (2008). See Table 1 and Appendix 1 for the whole dataset and references and Appendix 4 for modeling results. (For interpretation of the references to color in this figure legend, the reader is referred to the web version of this article.)

Hydrothermal seafloor alteration can greatly affect the $\mathrm{Sr}$ isotope signature of the subducting Altered Oceanic Crust.

$\left({ }^{87 / 86} \mathrm{Sr}_{\mathrm{AOC}}=0.70458\right.$, Staudigel et al., 1995). Nonetheless, this process does not alter its $\mathrm{Nd}$ and $\mathrm{Zn}$ isotope composition ( ${ }^{143}$ ${ }^{144} \mathrm{Nd}_{\mathrm{AOC}}=0.51308 ; \delta^{66} \mathrm{Zn}_{\mathrm{AOC}}=+0.27 \pm 0.01 \%$, Staudigel et al., 1995; Huang et al., 2016). Consequently, we argue that MORB-eclogite cannot account for the extreme $\mathrm{Zn}$ enrichment and global trends between $\mathrm{Zn}$ and $\mathrm{Zn}-\mathrm{Sr}-\mathrm{Nd}$ isotopes in oceanic basalts.

\subsection{Subducted sediment input}

Oceanic basalts are usually classified according to their affinity to hypothetical mantle reservoirs, such as the depleted MORB-mantle (DMM), a high ${ }^{238} \mathrm{U} /{ }^{204} \mathrm{~Pb}$ reservoir (HIMU) and distinct varieties of enriched mantle (EM I and II, Zindler and Hart, 1986; Willbold and Stracke, 2006,; Stracke et al., 2005; Hofmann, 1997). It is also widely accepted that these mantle end-members reflect, in part, the involvement of recycled sediments in the source of OIB (Hofmann and White, 1982; Weaver, 1991). On a single trench basis, subducting sediments exhibit substantial geochemical variability. Using the Global Subducting Sediment (GLOSS) composition of Plank (2014) would not capture this heterogeneity in our mixing model. Instead, we take the most Zn-poor (Mariana trench: $\mathrm{Zn}=64 \mathrm{pm}, \mathrm{Zn} / \mathrm{Fe}=15.5 \times 10^{4}$, $\mathrm{Sr}=161 \mathrm{ppm}, \mathrm{Nd}=21.0 \mathrm{ppm},{ }^{87 / 86} \mathrm{Sr}=0.70617$ and ${ }^{143 /}$ ${ }^{144} \mathrm{Nd}=0.51252$ ) and Zn-rich (Lesser Antilles trench: $\mathrm{Zn}=124 \mathrm{pm}$, 


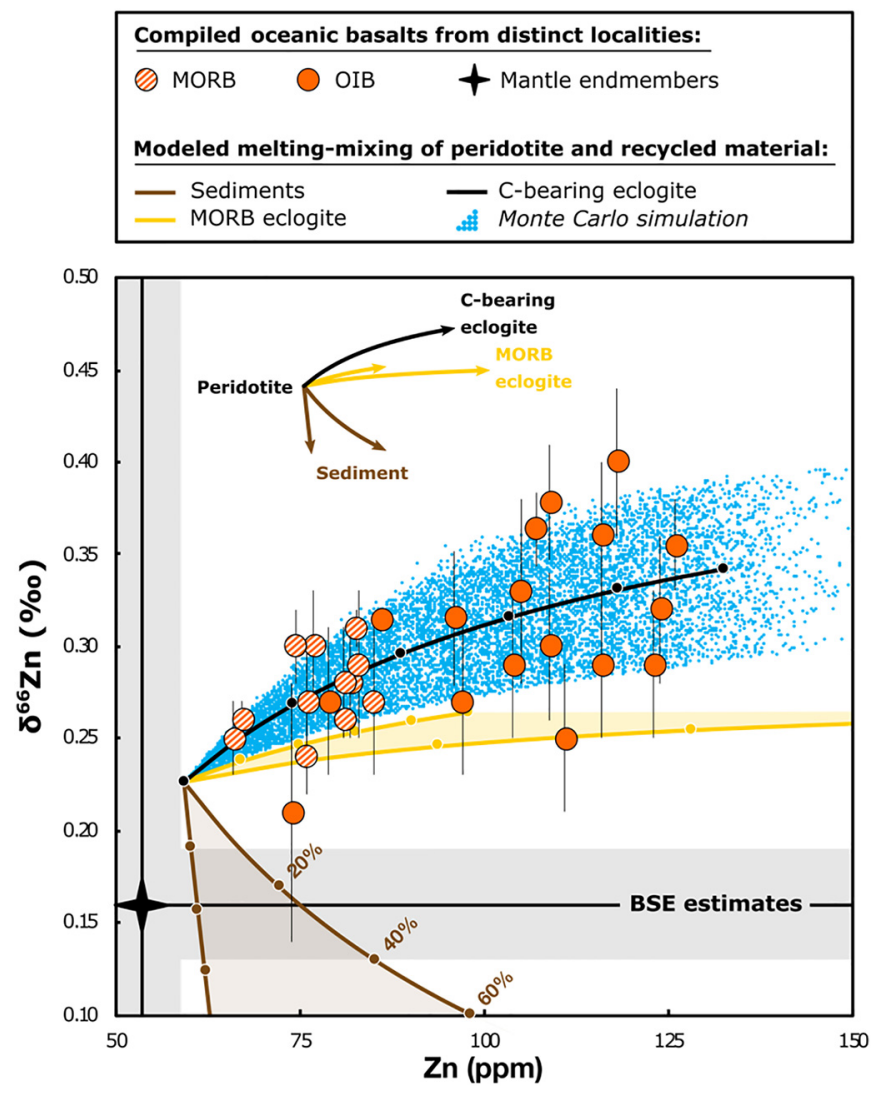

Fig. 5. Zn concentration (ppm) vs $\delta^{66} \mathrm{Zn}(\%)$ in oceanic basalts. Also shown are mixing curves between peridotite and sediments (brown curves and light brown field), MORB-eclogite (yellow curves and light yellow field) and C-bearing eclogite (black curve and blue dots overlay for the Monte Carlo simulation). See Table 1 and Appendix 1, 2 for the whole dataset and references and Appendix 4 for modeling results. (For interpretation of the references to color in this figure legend, the reader is referred to the web version of this article.)

$\mathrm{Zn} / \mathrm{Fe}=22.3 \times 10^{4}, \mathrm{Sr}=110 \mathrm{ppm}, \mathrm{Nd}=30.6 \mathrm{ppm},{ }^{87 /}$ ${ }^{86} \mathrm{Sr}=0.71585$ and ${ }^{143 / 144} \mathrm{Nd}=0.51197$ ) sediments from the compilation of Plank (2014) as possible end-members. Experimental constraints from Spandler et al., 2010 indicate that anhydrous metapelites are $\sim 90 \%$ molten at the locus of dry, fertile peridotite melting $\left(\sim 1440{ }^{\circ} \mathrm{C}\right.$ at $3 \mathrm{GPa}$, Hirschmann, 2000$)$. To our knowledge, the only $\mathrm{Zn}$ partitioning data available for metapelites are from Grassi et al. (2012) but have been determined at much higher pressure (8-22GPa). In the absence of experimental constrains in the P-T range of interest, we assume that sediments are completely molten for incipient melting (here $\mathrm{F}=1 \%$ ) of the surrounding peridotite mantle. Hence, we simply mix the peridotite-derived melt with the composition of sediments subducting at the Mariana and Lesser Antilles trenches in our model. An alternative melting model using bulk partition coefficients of anhydrous metapelites at 8GPa (Grassi et al., 2012, Table 3) is provided for comparison in Appendix 4 but does not alter the following conclusions. Resulting mixing arrays are systematically offset from the global trend defined by oceanic basalts (Figs. 3a, b and 4, brown curves and light brown field) predicting too high $\mathrm{Zn} / \mathrm{Fe}$ ratio and ${ }^{87 / 86} \mathrm{Sr}$, and too low ${ }^{143 / 144} \mathrm{Nd}$ at a given $\mathrm{Zn}$ content. While the $\mathrm{Zn}$ and $\mathrm{Sr}-\mathrm{Nd}$ isotope composition of at least some OIB could be readily explained by a threecomponent melting-mixing model of peridotite, MORB-eclogite and sediment sources, this scenario is clearly ruled out in a $\mathrm{Zn}$ vs $\mathrm{Zn} / \mathrm{Fe}$ space (Fig. 4). Similarly, both continental margin sediments $\left(\delta^{66} \mathrm{Zn}=+0.07 \pm 0.11\right.$, Little et al., 2016) and subducted metasediments $\left(\delta^{66} \mathrm{Zn}=+0.06 \pm 0.19\right.$, Inglis et al., 2017) display significantly lighter signatures than unaltered peridotites $\left(\delta^{66} \mathrm{Zn}=+0.18 \pm 0.06 \%\right)$ and oceanic basalts $\left(\delta^{66} \mathrm{Zn}\right.$ up to
$+0.40 \%$ ). Incorporation of subducted sediments in the mantle source of OIB cannot produce a heavy $\delta^{66} \mathrm{Zn}$ signature (Fig. 5). The latter outcome further precludes any three-component mixing between sediments, peridotite and MORB-eclogite derived melts.

\subsection{Carbon-bearing oceanic crust recycling}

A growing number of studies advocates for the presence of Cbearing eclogites as possible source lithologies responsible for major elements enrichment in OIB (Jackson and Dasgupta, 2008; Dasgupta et al., 2010). Given the large offset of $\delta^{66} \mathrm{Zn}$ between unmetasomatized peridotites $\left(\delta^{66} \mathrm{Zn}=+0.18 \pm 0.06 \%\right.$ ) and more heterogeneous marine carbonates $\left(\delta^{66} \mathrm{Zn}=+0.91 \pm 0.24 \%\right.$, Pichat et al., 2003; $+1.07 \pm 0.14 \%$, Little et al., 2016; up to +0.79 and $+0.87 \pm$ 0.14\%, Maréchal et al., 2000; Kunzmann et al., 2013), Zn isotopes are particularly well suited to track the carbon cycle at large scale (Liu et al., 2016; Liu and Li, 2019; Debret et al., 2018a). To our knowledge, Ravna et al. (2017) present the only available dataset of Zn concentration and Sr-Nd isotopic composition of C-bearing eclogites from ultrahigh-pressure metamorphic terranes $(n=4)$. These samples contain $\geq 5 \%$ of carbonates and have been interpreted to be fragments of a deeply subducted slab. Most importantly, they fulfill all the geochemical requirements discussed in Section 3.2: extremely high $\mathrm{Zn}$ concentration $(111 \pm 9 \mathrm{pm})$ and $\mathrm{Zn} / \mathrm{Fe}$ ratio $\left(10.1 \pm 1.7 \times 10^{4}\right)$, radiogenic $\mathrm{Sr}\left({ }^{87 / 86} \mathrm{Sr}=0.70638\right.$ and $\left.\mathrm{Sr}=132 \pm 34 \mathrm{ppm}\right)$ and unradiogenic $\mathrm{Nd}\left({ }^{143 / 144} \mathrm{Nd}=0.51249\right.$ and $\mathrm{Nd}=7.4 \pm 3.5 \mathrm{ppm}$, Ravna et al., 2017) isotope signatures compared to unaltered peridotites and MORB-eclogites. Unfortunately, no Zn isotope measurements have been reported for C-bearing eclogites yet. Considering the apparent lack of $\delta^{66} \mathrm{Zn}$ fractionation during prograde metamorphism and dehydration of the subducted crust (see Section 3.1.3), the Zn isotope composition of deep-sea marine and high-pressure carbonates associated with the metamorphic crust is presumed to remain unchanged during subduction. To estimate the $\delta^{66} \mathrm{Zn}$ composition of such lithology, we assume that the bulk C-bearing eclogite is a mixture of 90-95\% MORB-eclogite $\left(\mathrm{Zn}=91 \mathrm{ppm}\right.$ and $\delta^{66} \mathrm{Zn}=+0.27 \pm 0.08 \%$, Gale et al., 2013; Inglis et al., 2017) and 5-10\% high-pressure carbonates ( $\mathrm{Zn}=130 \mathrm{ppm}$ and $\delta^{66} \mathrm{Zn}=+0.91 \pm 0.24 \%$, Li et al., 2014; Pichat et al., 2003; modal proportions after Ravna et al., 2017). Hence, we find a bulk $\delta^{66} \mathrm{Zn}$ of +0.30 to $+0.35 \%$ for C-bearing eclogites. Considering a mineral assemblage of $60 \% \mathrm{Cpx}+35 \% \mathrm{Gt}+5 \% \mathrm{Carb}$ and the corresponding mineral-melt exchange coefficients (Table 3, Ravna et al., 2017; Le Roux et al., 2015; Sweeney et al., 1995) we find a bulk $D_{Z n}{ }^{C A R B e c l-m e l t}$ and $D_{Z n / F e}$ CARBecl-melt of 0.73 and 0.50 , respectively. The solidus and melt productivity of C-bearing eclogites is less constrained than that of typical MORB-eclogites (see Yaxley and Brey, 2004; Hammouda, 2003; Dasgupta et al., 2004; Kiseeva et al., 2012 for further discussion). Here, we assume that C-bearing eclogites are $60 \%$ molten for incipient melting (here $\mathrm{F}=1 \%$ ) of the surrounding peridotite, similarly to MORB-eclogites. The modeled melting-mixing curves between the peridotite and C-bearing eclogite melts (black lines) and results from our Monte Carlo simulation (blue dots overlay) accounting for the compositional variability of C-bearing eclogites from Ravna et al. (2017) are plotted in Figs. 3a, b and 4. Melting of C-bearing eclogite is thus capable of generating high $\mathrm{Zn}$ concentrations ( $\sim 125 \mathrm{ppm})$ associated with heavy $\delta^{66} \mathrm{Zn}(\sim+0.35 \%)$, radiogenic $\mathrm{Sr}\left({ }^{87 / 86} \mathrm{Sr} \sim 0.706\right)$ and unradiogenic $\mathrm{Nd}\left({ }^{143 / 144} \mathrm{Nd} \sim 0.51250\right)$ signatures. Most strikingly, both mixing curves and Monte Carlo results overlap remarkably well with the whole trend of oceanic basalts in $\mathrm{Zn}$ vs $\mathrm{Zn} / \mathrm{Fe}, \delta^{66} \mathrm{Zn},{ }^{87 / 86} \mathrm{Sr}$ and ${ }^{143 / 144} \mathrm{Nd}$ spaces. Based on these results, we argue that C-bering oceanic crust recycling is thus a viable mechanism to explain the $\mathrm{Zn}$ heterogeneity of oceanic basalts.

\subsection{Assessment of eclogite-bearing plume buoyancy}

Comparing the Zn composition of oceanic basalts to modeled mixing 
curves allow us to estimate the fraction of peridotite and C-bearing eclogite melts required to generate the $\mathrm{Zn}$ enrichment of OIB. Most of their $\mathrm{Zn}$ composition can be explained with a $20: 80$ to $80: 20 \mathrm{mix}$ of melts from a peridotite and C-bearing eclogite source, respectively (e.g., Fig. 3a, b). C-bearing eclogites have higher melt productivity and a lower solidus than dry peridotites, contributing more to the final hybrid melt (Kogiso, 2004; Leitch and Davies, 2001). Hence, their true proportion in the source of OIB ( $X_{C-\text { bearing ecl }}$ in \%) can be inferred using the equation from Le Roux et al. (2011):

$X_{A}=\left(f_{A} * 100\right) /\left(f_{A}+f_{B}\right)$

where $f_{A, B}$ is function of the fraction of melt $\left(f_{A, B}\right.$ melt $)$ and degree of melting $\left(F_{A, B}\right)$ of the source components A and B $\left(f_{A, B}=f_{A, B \text { melt }} / F_{A, B}\right)$ in the hybrid melt. The 20:80 and 80:20 mixes mentioned above correspond to $0.4-6 \%$ of C-bearing eclogite in the source of OIB. The density of eclogites varies with their carbon content, slightly decreasing from $3500 \mathrm{~kg} / \mathrm{m}^{3}$ in typical MORB-eclogite to $3447.5 \mathrm{~kg} / \mathrm{m}^{3}$ in MORBeclogite containing $5 \mathrm{wt} \% \mathrm{CO}_{2}$ (Pertermann and Hirschmann, 2003; Sanchez-Valle et al., 2011). In any case, eclogites are significantly denser than the surrounding peridotite mantle $\left(\rho_{\text {peridotite }}=3300 \mathrm{~kg}\right.$ / $\mathrm{m}^{3}$, Pertermann and Hirschmann, 2003). The capacity of mantle plumes to carry C-bearing eclogites results from the competitive effect of their compositional (e.g., the proportion of dense material in the plume) and thermal (e.g., thermal anomalies compared to the surrounding mantle) buoyancies (Davies, 2011). Hence, the variable proportion of C-bearing eclogites required to explain the range of $\mathrm{Zn}$ enrichment in OIB could either reflect (1) the heterogeneous distribution of recycled material in the mantle, or (2) distinct plume thermal anomalies, or both. To assess the viability of the latter hypothesis, we estimated the average temperature of magma generation of MORB and OIB (1 bar liquidus temperature, Table 1) using the thermometer of Lee et al. (2009). While Zn partitioning varies little with changes in temperature (bulk $D_{Z n \text {, low-. }}$ ${ }_{T}^{\text {peridotite-melt }}=0.88$ and $D_{Z n \text {, high-T }}$ peridotite-melt $=0.82$, Le Roux et al., 2011) we find a striking positive correlation between the temperature of magma generation and their average $\mathrm{Zn}$ content (Fig. $6 \mathrm{a}, \mathrm{R}^{2}=0.82$ ) supporting a link between thermal anomalies and the proportion of $\mathrm{C}$ bearing eclogite entrained in the plume. This observation is tempered by the Hawaiian case which is by fat the most buoyant hotspot (Steinberger, 2000; King and Adam, 2014). Indeed, Hawaiian basalts display a relatively limited $\mathrm{Zn}$ enrichment $(103 \pm 13 \mathrm{ppm})$ compared to some other OIB (e.g., $124 \pm 7 \mathrm{ppm}$ for Society islands). Although a detailed evaluation of mantle plume dynamics is beyond the scope of this paper, we note two broad independent positive trends between average Zn content and hostspot buoyancy fluxes for tholeiitic (e.g., Hawaii, Iceland, Galapagos) and alkalic ocean islands (Fig. 6b, King and Adam, 2014). Such variation might be attributed to additional parameters impacting OIB composition (e.g., heterogeneous distribution of recycled material in the mantle, degrees of partial melting, magma fluxes) suggesting that thermal buoyancy is likely not the only mechasinm at play.

The maximum proportion of any dense material $\left(X_{A}\right.$ in \%) to preserve a positive buoyancy depends linearly on the plume excess temperature $\left(\Delta T\right.$ in ${ }^{\circ} \mathrm{C}$, Leitch and Davies, 2001):

$X_{A}=\alpha \rho_{0} \Delta T /\left(\rho_{A}+\rho_{0}\right)$

where $\alpha$ is the coefficient of thermal expansion $\left({ }^{\circ} \mathrm{C}^{-1}\right), \rho_{\mathrm{A}}$ and $\rho_{0}$ are the density of component $\mathrm{A}$ and the surrounding plume mantle, respectively. For temperature anomalies up to $200{ }^{\circ} \mathrm{C}$ observed in OIB relative to the normal upper mantle (e.g. average $\mathrm{T}_{\mathrm{MORB}} \sim 1400{ }^{\circ} \mathrm{C}$, Fig. $6 \mathrm{a}$ ) and assuming $\rho_{\mathrm{C} \text {-bearing ecl }}=3447.5 \mathrm{~kg} / \mathrm{m}^{3}, \rho_{\text {peridotite }}=3300 \mathrm{~kg} / \mathrm{m}^{3}$ and $\alpha$ of $2-5.10^{-5}{ }^{\circ} \mathrm{C}^{-1}$ (Pertermann and Hirschmann, 2003) the relative amount of C-bearing eclogite in the plume should not exceed $9-22 \%$. This result is significantly higher and compatible with our estimation of 0.4-6\% C-bearing eclogite in mantle plumes inferred from $\mathrm{Zn}$ systematics in OIB.
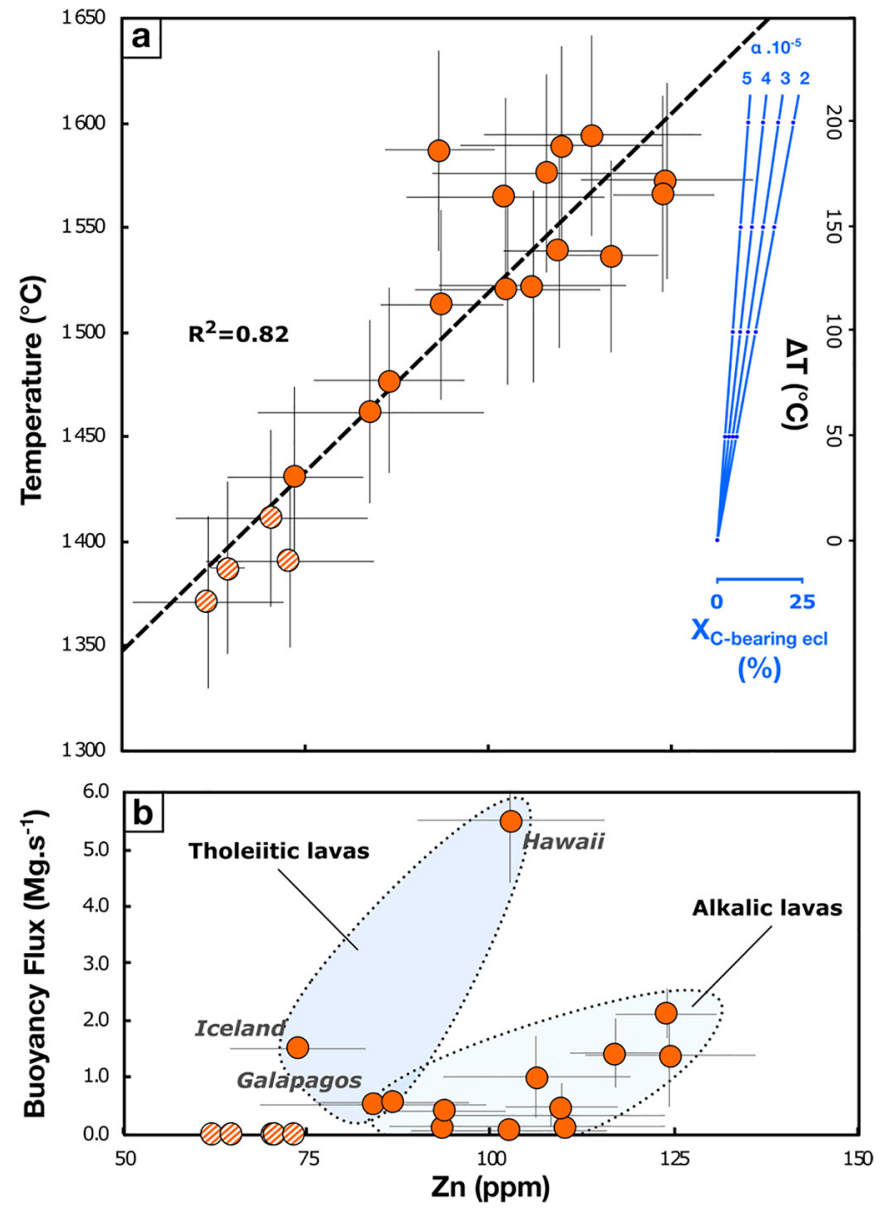

Fig. 6. Average Zn concentration (ppm) vs (a) temperature of magma generation $\left({ }^{\circ} \mathrm{C}\right)$ inferred from the thermometer of Lee et al. (2009) and (b) average hotspot buoyancy fluxes (Mg.s ${ }^{-1}$ ) calculated from cross-sectional and MiFil area (King and Adam, 2014). Temperatures are also given in terms of temperatures excess relative to the average temperature of $\sim 1400{ }^{\circ} \mathrm{C}$ calculated for $\operatorname{MORB}\left(\Delta \mathrm{T}\right.$ in ${ }^{\circ} \mathrm{C}$, top axis). Also shown is the maximum proportion of C-bearing eclogite in the plume ( $\mathrm{X}_{\mathrm{C} \text {-bearing ecl }}$ in $\%$ ) at a given $\Delta \mathrm{T}$ to preserve a positive plume buoyancy using coefficients of thermal expansion of $2,3,4$ and $5.10^{-5}{ }^{\circ} \mathrm{C}^{-1}$ (blue curves, see text for details). In figure (b), MORB are re-


(For interpretation of the references to color in this figure legend, the reader is referred to the web version of this article.)

\subsection{Implications and perspectives for the Deep Carbon Cycle}

Over the past few years, lot of attention has been given to the deep carbon cycle, arguing whether or not, long term carbon cycling is in equilibria between mantle carbon degassing, through partial melting and magmatic degassing processes, and deep recycling into the mantle by subduction (e.g., Kelemen and Manning, 2015 and references therein). These discrepancies emphasize the difficulty in determining the extent to which carbon (present in the form of inorganic and organic compounds) is mobilized in slab derived fluids during subduction, and whether some of this carbon may return to the deep mantle.

As demonstrated here and in previous studies (e.g., Eguchi et al., 2020), the composition of OIB involve melting of C-bearing recycled crustal components in the convecting mantle, and can place new constraints on the role of subduction on deep carbon recycling over geological times. Although $\mathrm{C}$ or $\mathrm{CO}_{2}$ data for oceanic basalts and especially OIB remain scarce, studies have shown that $\mathrm{CO}_{2} / \mathrm{Rb}$ and $\mathrm{CO}_{2} / \mathrm{Ba}$ ratios are constant in undegassed samples (Hauri et al., 2018; Cartigny et al., 2008; Shimizu et al., 2016). As such, Rb and/or Ba can be used as proxies for the primary $\mathrm{CO}_{2}$ content of oceanic basalts (Hauri et al., 

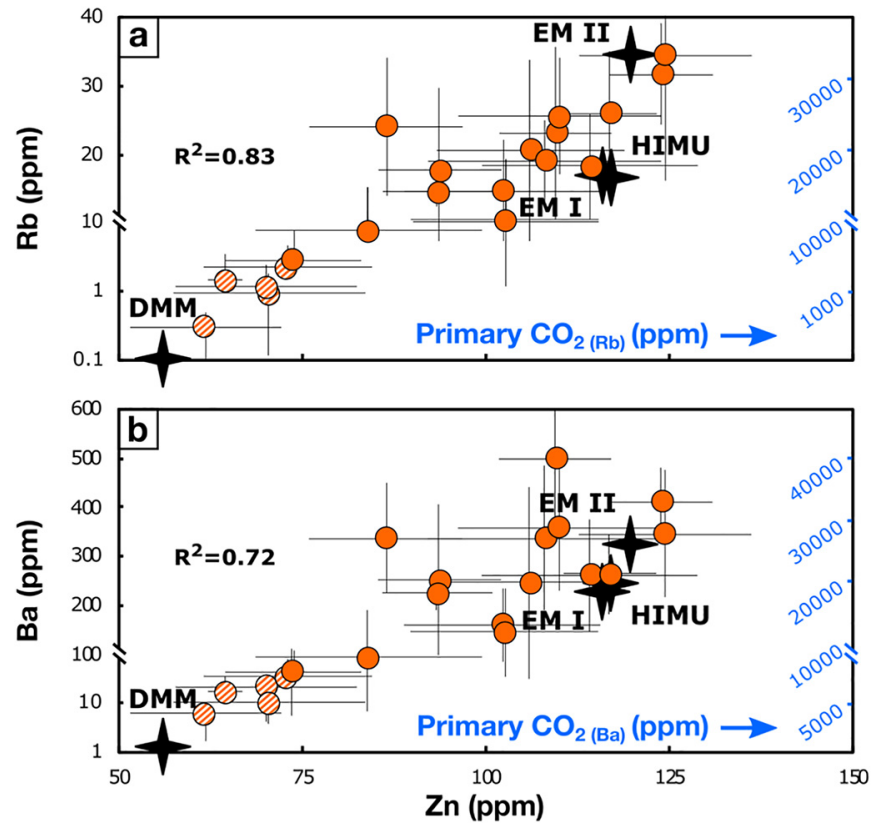

Fig. 7. Average Zn concentration (ppm) vs (a) Rb and (b) Ba (ppm) in oceanic basalts. Primary undegassed $\mathrm{CO}_{2}$ contents (right axis) are calculated using recommended $\mathrm{CO}_{2} / \mathrm{Rb}$ and $\mathrm{CO}_{2} / \mathrm{Ba}$ ratios of $991 \pm 26 \%$ and $81.3 \pm 56 \%$, respectively (Hauri et al., 2018). Depleted-MORB Mantle (DMM) estimates from Salters and Stracke (2004) and EM I, EM II and HIMU end-members calculated from our compilation and following the method of Jackson and Dasgupta (2008). See Table 1 and Appendix 1 for the whole dataset and references.

2018, 2019; Le Voyer et al., 2019). Using our compilation of near-primary basalts for individual ridges and hotspots, we estimate their average primary $\mathrm{CO}_{2}$ content and compare it to their $\mathrm{Zn}$ concentrations (Fig. 7a, b). Zinc appears to be positively correlated to $\mathrm{Rb}\left(\mathrm{R}^{2}=0.83\right.$ ) and $\mathrm{Ba}\left(\mathrm{R}^{2}=0.72\right)$, and in turn, to the inferred primary $\mathrm{CO}_{2}$ content of OIB. This clearly underlines a direct link between the amount of carbon and subducted C-bearing recycled crustal material in the source of OIB. In addition, these results point towards a deep recycling of carbon during subduction.

Changes in the long term carbon cycle through geological times could be driven by modification of the fraction of organic relative to inorganic carbon buried by subduction (e.g., Duncan and Dasgupta, 2017; Eguchi et al., 2020). Non-traditional stable isotope fractionations are expected to be driven by various inorganic (hydrated cation, hydroxide, chloride, sulfate, sulfide, phosphate) and organic (citrate, amino acid) complexes (Fujii et al., 2011, 2014; Moynier et al., 2017). The use of such systems in OIB have therefore the potential to reveal modifications on the nature of recycled carbon into the deep mantle through geological times. Given that both inorganic and organic carbon are expected to display isotopically light $\mathrm{Zn}$ signature (Fujii et al., 2014), the sole use of $\mathrm{Zn}$ isotopes cannot fully constrain the nature of this recycled carbon. Further investigations will required systematic data on OIB for both $\mathrm{Zn}$ and other stable isotopic tracers that are sensitive to carbon speciation and poorly affected by magmatic differentiation and degassing (e.g., Ca and Cu isotopes; Moynier et al., 2017; Moynier and Fujii, 2017; Fujii et al., 2014). Unfortunately, such complementary $\mathrm{Zn}$-Ca-Cu isotope data in OIB are at that time absent from the literature. Similarily, the combination of $\mathrm{Zn}$ stable isotopes with other isotopic tracers (e.g., Re-Os) will certainly help to further investigate the variability, the source (mantle versus subduction derived) and certainly the age of deep carbon in the source of OIB.

\section{Conclusions}

Zinc elemental and isotopic composition of oceanic basalts differs according to their tectonic settings, increasing from ridges to ocean islands. Unlike MORB, the high $\mathrm{Zn}$ and $\delta^{66} \mathrm{Zn}$ recorded in OIB cannot be explained by partial melting of a fertile peridotite mantle source only. Importantly, global correlations between $\mathrm{Zn}$ content and $\mathrm{Sr}$-Nd isotopes in oceanic basalts suggest that the $\mathrm{Zn}$ enrichment in OIB is inherited from a recycled component in their mantle source rather than melting processes.

We demonstrate that involvement of neither typical MORB-like oceanic crust nor subducted sediments can achieve the whole range of $\mathrm{Zn}$ composition in OIB. Instead, addition of $0.4-6 \%$ C-bearing oceanic crust to a fertile peridotite mantle fully resolves the $\mathrm{Zn}$ heterogeneity of OIB, both in terms of magnitude of $\mathrm{Zn}$ enrichment and global trends with Sr-Nd isotopes. Such scenario is corroborated by the elevated $\delta^{66} \mathrm{Zn}$ of OIB relative to MORB and mantle peridotites, reflecting the contribution of isotopically heavy carbonates to the mantle source. Additionally, abundances of $\mathrm{Zn}$ and inferred primary $\mathrm{CO}_{2}$ content of oceanic basalts are well-correlated which further supports the link between recycling of C-bearing subducted material and the amount of carbon in the source regions of OIB. Hence, $\mathrm{Zn}$ and $\delta^{66} \mathrm{Zn}$ systematics may provide a valuable tool to fingerprint deep carbon cycling in the Earth's mantle.

Finally, the positive correlation between $\mathrm{Zn}$ content and temperature of magma generation of oceanic basalts suggests that hotter mantle plumes are more likely to carry a higher proportion of dense C-bearing eclogite. Zn systematics therefore may provide evidence that the presence of heterogeneous domains in the source of OIB is linked to plume thermal buoyancy, bringing new insights into mantle dynamics.

\section{Declaration of competing interest}

None.

\section{Acknowledgements}

This research was supported by the F.N.R.S (Fond National de la Recherche Scientifique, Belgium) $n^{\circ} 1141117 \mathrm{~F}$ to HB. HB acknowledges his F.R.S.-F.N.R.S. research fellowship (Aspirant). The authors wish to thank J. De Jong (ULB) for technical support during MC-ICP-MS analyses. We are grateful to the thorough and detailed reviews from Veronique Le Roux and Paolo Sossi and from the editor, Arturo GomezTuena. We also thank Cin-Ty Lee for helpful discussion and critical comments on earlier version of this article.

\section{Appendix A. Supplementary data}

Supplementary data to this article can be found online at https:// doi.org/10.1016/j.earscirev.2020.103174.

\section{References}

Anderson, D.L., 2006. Speculations on the nature and cause of mantle heterogeneity. Tectonophysics 416, 7-22. https://doi.org/10.1016/j.tecto.2005.07.011.

Black, J.R., Kavner, A., Schauble, E.A., 2011. Calculation of equilibrium stable isotope partition function ratios for aqueous zinc complexes and metallic zinc. Geochim. Cosmochim. Acta 75, 769-783. https://doi.org/10.1016/j.gca.2010.11.019.

Blundy, J., Wood, B., 2003. Partitioning of trace elements between crystals and melts. Earth Planet. Sci. Lett. 210, 383-397. https://doi.org/10.1016/S0012-821X(03) 00129-8.

Breton, T., Nauret, F., Pichat, S., Moine, B., Moreira, M., Rose-Koga, E.F., Auclair, D., Bosq, C., Wavrant, L.-M., 2013. Geochemical heterogeneities within the Crozet hotspot. Earth Planet. Sci. Lett. 376, 126-136. https://doi.org/10.1016/j.epsl.2013.06. 020 .

Cartigny, P., Pineau, F., Aubaud, C., Javoy, M., 2008. Towards a consistent mantle carbon flux estimate: insights from volatile systematics $(\mathrm{H} 2 \mathrm{O} / \mathrm{Ce}, \delta \mathrm{D}, \mathrm{CO} 2 / \mathrm{Nb})$ in the North Atlantic mantle $\left(14^{\circ} \mathrm{N}\right.$ and $\left.34^{\circ} \mathrm{N}\right)$. Earth Planet. Sci. Lett. 265, 672-685. https://doi. org/10.1016/j.epsl.2007.11.011.

Chen, H., Savage, P.S., Teng, F.-Z., Helz, R.T., Moynier, F., 2013. Zinc isotope fractionation during magmatic differentiation and the isotopic composition of the bulk Earth. Earth Planet. Sci. Lett. 369-370, 34-42. https://doi.org/10.1016/j.epsl.2013. 02.037.

Courtillot, V., Davaille, A., Besse, J., Stock, J., 2003. Three distinct types of hotspots in the 
Earth's mantle. Earth Planet. Sci. Lett. 205, 295-308. https://doi.org/10.1016/ S0012-821X(02)01048-8.

Dasgupta, R., Hirschmann, M.M., Withers, A.C., 2004. Deep global cycling of carbon constrained by the solidus of anhydrous, carbonated eclogite under upper mantle conditions. Earth Planet. Sci. Lett. 227, 73-85. https://doi.org/10.1016/j.epsl.2004. 08.004 .

Dasgupta, R., Jackson, M.G., Lee, C.-T.A., 2010. Major element chemistry of ocean island basalts - conditions of mantle melting and heterogeneity of mantle source. Earth Planet. Sci. Lett. 289, 377-392. https://doi.org/10.1016/j.epsl.2009.11.027.

Davies, G.F., 2011. Mantle Convection for Geologists. Cambridge University Press, Cambridge. https://doi.org/10.1017/CBO9780511973413.

Davis, F.A., Humayun, M., Hirschmann, M.M., Cooper, R.S., 2013. Experimentally determined mineral/melt partitioning of first-row transition elements (FRTE) during partial melting of peridotite at 3GPa. Geochim. Cosmochim. Acta 104, 232-260. https://doi.org/10.1016/j.gca.2012.11.009.

Debret, B., Millet, M.-A., Pons, M.-L., Bouilhol, P., Inglis, E., Williams, H., 2016. Isotopic evidence for iron mobility during subduction. Geology 44, 215-218. https://doi.org/ 10.1130/G37565.1.

Debret, B., Beunon, H., Mattielli, N., Andreani, M., Ribeiro da Costa, I., Escartin, J., 2018a. Ore component mobility, transport and mineralization at mid-oceanic ridges: a stable isotopes ( $\mathrm{Zn}, \mathrm{Cu}$ and $\mathrm{Fe}$ ) study of the Rainbow massif (Mid-Atlantic Ridge $\left.36^{\circ} 14^{\prime} \mathrm{N}\right)$. Earth Planet. Sci. Lett. 503, 170-180. https://doi.org/10.1016/j.epsl.2018. 09.009.

Debret, B., Bouilhol, P., Pons, M.L., Williams, H., 2018b. Carbonate transfer during the onset of slab devolatilization: new insights from $\mathrm{Fe}$ and $\mathrm{Zn}$ stable isotopes. J. Petrol. 59, 1145-1166. https://doi.org/10.1093/petrology/egy057.

DePaolo, D.J., 1981. Trace element and isotopic effects of combined wallrock assimilation and fractional crystallization. Earth Planet. Sci. Lett. 53, 189-202. https://doi.org/ 10.1016/0012-821X(81)90153-9.

Doe, B.R., 1995. Zinc, copper, and lead geochemistry of oceanic igneous rocks-ridges, islands, and arcs. Int. Geol. Rev. 37, 379-420. https://doi.org/10.1080/ 00206819509465410.

Doucet, L.S., Mattielli, N., Ionov, D.A., Debouge, W., Golovin, A.V., 2016. Zn isotopic heterogeneity in the mantle: a melting control? Earth Planet. Sci. Lett. 451, 232-240. https://doi.org/10.1016/j.epsl.2016.06.040.

Ducher, M., Blanchard, M., Balan, E., 2016. Equilibrium zinc isotope fractionation in Znbearing minerals from first-principles calculations. Chem. Geol. 443, 87-96. https:// doi.org/10.1016/j.chemgeo.2016.09.016.

Duncan, M.S., Dasgupta, R., 2017. Rise of Earth's atmospheric oxygen controlled by efficient subduction of organic carbon. Nat. Geosci. 10, 387-392. https://doi.org/10. 1038/ngeo2939.

Eguchi, J., Seales, J., Dasgupta, R., 2020. Great oxidation and Lomagundi events linked by deep cycling and enhanced degassing of carbon. Nat. Geosci. 13, 71-76. https:// doi.org/10.1038/s41561-019-0492-6.

Ewart, A., Griffin, W.L., 1994. Application of proton-microprobe data to trace-element partitioning in volcanic rocks. Chem. Geol. 117, 251-284. https://doi.org/10.1016/ 0009-2541(94)90131-7.

Frost, D.J., McCammon, C.A., 2008. The redox state of earth's mantle. Annu. Rev. Earth Planet. Sci. 36, 389-420. https://doi.org/10.1146/annurev.earth.36.031207. 124322.

Fujii, T., Moynier, F., Pons, M.-L., Albarède, F., 2011. The origin of Zn isotope fractionation in sulfides. Geochim. Cosmochim. Acta 75, 7632-7643. https://doi.org/10. 1016/j.gca.2011.09.036

Fujii, T., Moynier, F., Blichert-Toft, J., Albarède, F., 2014. Density functional theory estimation of isotope fractionation of $\mathrm{Fe}, \mathrm{Ni}, \mathrm{Cu}$, and $\mathrm{Zn}$ among species relevant to geochemical and biological environments. Geochim. Cosmochim. Acta 140, 553-576. https://doi.org/10.1016/j.gca.2014.05.051.

Gale, A., Dalton, C.A., Langmuir, C.H., Su, Y., Schilling, J.-G., 2013. The mean composition of ocean ridge basalts. Geochem. Geophys. Geosyst. 14, 489-518. https://doi org/10.1029/2012GC004334.

Grassi, D., Schmidt, M.W., Günther, D., 2012. Element partitioning during carbonated pelite melting at 8,13 and $22 \mathrm{GPa}$ and the sediment signature in the EM mantle components. Earth Planet. Sci. Lett. 327-328, 84-96. https://doi.org/10.1016/j.epsl. 2012.01.023.

Hammouda, T., 2003. High-pressure melting of carbonated eclogite and experimental constraints on carbon recycling and storage in the mantle. Earth Planet. Sci. Lett. 214, 357-368. https://doi.org/10.1016/S0012-821X(03)00361-3.

Hauri, E.H., Maclennan, J., McKenzie, D., Gronvold, K., Oskarsson, N., Shimizu, N., 2018. $\mathrm{CO} 2$ content beneath northern Iceland and the variability of mantle carbon. Geology 46, 55-58. https://doi.org/10.1130/G39413.1.

Hauri, E.H., Cottrell, E., Kelley, K.A., Tucker, J.M., Shimizu, K., Voyer, M.L., Marske, J., Saal, A.E., 2019. Carbon in the convecting mantle. In: Orcutt, B.N., Daniel, I., Dasgupta, R. (Eds.), Deep Carbon: Past to Present. Cambridge University Press, pp. 237-275.

Herzberg, C., 2006. Petrology and thermal structure of the Hawaiian plume from Mauna Kea volcano. Nature 444, 605-609. https://doi.org/10.1038/nature05254.

Hirschmann, M.M., 2000. Mantle solidus: experimental constraints and the effects of peridotite composition: MANTLE SOLIDUS. Geochem. Geophys. Geosyst. 1. https:// doi.org/10.1029/2000GC000070.

Hoefs, J., 2018. Stable Isotope Geochemistry, Springer Textbooks in Earth Sciences, Geography and Environment. Springer International Publishing, Cham. https://doi. org/10.1007/978-3-319-78527-1.

Hofmann, A.W., 1997. Mantle geochemistry: the message from oceanic volcanism. Nature 385, 219-229. https://doi.org/10.1038/385219a0.

Hofmann, A.W., White, W.M., 1982. Mantle plumes from ancient oceanic crust. Earth Planet. Sci. Lett. 57, 421-436. https://doi.org/10.1016/0012-821X(82)90161-3.

Huang, J., Liu, S.-A., Gao, Y., Xiao, Y., Chen, S., 2016. Copper and zinc isotope systematics of altered oceanic crust at IODP Site 1256 in the eastern equatorial Pacific: oceanic ccrust Cu-Zn isotopic composition. J. Geophys. Res. Solid Earth 121, 7086-7100. https://doi.org/10.1002/2016JB013095.
Huang, J., Chen, S., Zhang, X.-C., Huang, F., 2018a. Effects of melt percolation on Zn isotope heterogeneity in the mantle: constraints from Peridotite Massifs In IvreaVerbano Zone, Italian Alps. J. Geophys. Res. Solid Earth 123, 2706-2722. https://doi org/10.1002/2017JB015287.

Huang, J., Zhang, X.-C., Chen, S., Tang, L., Wörner, G., Yu, H., Huang, F., 2018b. Zinc isotopic systematics of Kamchatka-Aleutian arc magmas controlled by mantle melting. Geochim. Cosmochim. Acta 238, 85-101. https://doi.org/10.1016/j.gca. 2018.07.012.

Humayun, M., 2004. Geochemical evidence for excess iron in the mantle beneath Hawaii. Science 306, 91-94. https://doi.org/10.1126/science.1101050.

Inglis, E.C., Debret, B., Burton, K.W., Millet, M.-A., Pons, M.-L., Dale, C.W., Bouilhol, P., Cooper, M., Nowell, G.M., McCoy-West, A.J., Williams, H.M., 2017. The behavior of iron and zinc stable isotopes accompanying the subduction of mafic oceanic crust: a case study from Western Alpine ophiolites: Fe and $\mathrm{Zn}$ isotopes during subduction. Geochem. Geophys. Geosyst. 18, 2562-2579. https://doi.org/10.1002/ 2016GC006735.

Jackson, M.G., Dasgupta, R., 2008. Compositions of HIMU, EM1, and EM2 from global trends between radiogenic isotopes and major elements in ocean island basalts. Earth Planet. Sci. Lett. 276, 175-186. https://doi.org/10.1016/j.epsl.2008.09.023.

Jenner, F.E., O'Neill, H.St.C., 2012. Major and trace analysis of basaltic glasses by laserablation ICP-MS. Geochem. Geophys. Geosyst. 13. https://doi.org/10.1029/ 2011 GC003890.

John, T., Scherer, E.E., Schenk, V., Herms, P., Halama, R., Garbe-Schönberg, D., 2010 Subducted seamounts in an eclogite-facies ophiolite sequence: the Andean Raspas complex, SW Ecuador. Contrib. Mineral. Petrol. 159, 265-284. https://doi.org/10. 1007/s00410-009-0427-0.

Kelemen, P.B., Manning, C.E., 2015. Reevaluating carbon fluxes in subduction zones, what goes down, mostly comes up. Proc. Natl. Acad. Sci. U. S. A. 112, E3997-E4006. https://doi.org/10.1073/pnas.1507889112.

King, S.D., Adam, C., 2014. Hotspot swells revisited. Phys. Earth Planet. Inter. 235, 66-83. https://doi.org/10.1016/j.pepi.2014.07.006.

Kiseeva, E.S., Yaxley, G.M., Hermann, J., Litasov, K.D., Rosenthal, A., Kamenetsky, V.S. 2012. An experimental study of carbonated eclogite at 3 \{middle dot $5-5$ \{middle dot $5 \mathrm{GPa}$ - implications for silicate and carbonate metasomatism in the cratonic mantle. J. Petrol. 53, 727-759. https://doi.org/10.1093/petrology/egr078.

Kitajima, K., Maruyama, S., Utsunomiya, S., Liou, J.G., 2001. Seafloor hydrothermal alteration at an Archaean mid-ocean ridge. J. Metamorph. Geol. 19, 583-599. https:// doi.org/10.1046/j.0263-4929.2001.00330.x.

Kogiso, T., 2004. High-pressure partial melting of mafic lithologies in the mantle. J. Petrol. 45, 2407-2422. https://doi.org/10.1093/petrology/egh057.

Krienitz, M.-S., Garbe-Schönberg, C.-D., Romer, R.L., Meixner, A., Haase, K.M., Stroncik, N.A., 2012. Lithium isotope variations in ocean island basalts-implications for the development of mantle heterogeneity. J. Petrol. 53, 2333-2347. https://doi.org/10. 1093/petrology/egs052.

Kunzmann, M., Halverson, G.P., Sossi, P.A., Raub, T.D., Payne, J.L., Kirby, J., 2013. Zn isotope evidence for immediate resumption of primary productivity after snowball Earth. Geology 41, 27-30. https://doi.org/10.1130/G33422.1.

Lee, C.-T.A., Luffi, P., Roux, V., Dasgupta, R., Albaréde, F., Leeman, W.P., 2010. The redox state of arc mantle using Zn/Fe systematics. Nature 468, 681-685. https://doi.org/ 10.1038/nature09617.

Le Roux, V., Lee, C.-T.A., Turner, S.J., 2010. Zn/Fe systematics in mafic and ultramafic systems: implications for detecting major element heterogeneities in the Earth's mantle. Geochim. Cosmochim. Acta 74, 2779-2796. https://doi.org/10.1016/j.gca. 2010.02.004.

Le Roux, V., Dasgupta, R., Lee, C.-T.A., 2011. Mineralogical heterogeneities in the Earth's mantle: constraints from $\mathrm{Mn}, \mathrm{Co}, \mathrm{Ni}$ and $\mathrm{Zn}$ partitioning during partial melting. Earth Planet. Sci. Lett. 307, 395-408. https://doi.org/10.1016/j.epsl.2011.05.014.

Le Roux, V., Dasgupta, R., Lee, C.-T.A., 2015. Recommended mineral-melt partition coefficients for FRTEs (Cu), Ga, and Ge during mantle melting. Am. Mineral. 100, 2533-2544. https://doi.org/10.2138/am-2015-5215.

Le Voyer, M., Hauri, E.H., Cottrell, E., Kelley, K.A., Salters, V.J.M., Langmuir, C.H., Hilton, D.R., Barry, P.H., Füri, E., 2019. Carbon fluxes and primary magma CO 2 contents along the global mid-ocean ridge system. Geochem. Geophys. Geosyst. 20, 1387-1424. https://doi.org/10.1029/2018GC007630.

Lee, C.-T.A., Luffi, P., Plank, T., Dalton, H., Leeman, W.P., 2009. Constraints on the depths and temperatures of basaltic magma generation on Earth and other terrestrial planets using new thermobarometers for mafic magmas. Earth Planet. Sci. Lett. 279, 20-33. https://doi.org/10.1016/j.epsl.2008.12.020.

Leitch, A.M., Davies, G.F., 2001. Mantle plumes and flood basalts: enhanced melting from plume ascent and an eclogite component. J. Geophys. Res. 106, 2047-2059. https:// doi.org/10.1029/2000JB900307.

Li, J.-L., Klemd, R., Gao, J., Meyer, M., 2014. Compositional zoning in dolomite from lawsonite-bearing eclogite (SW Tianshan, China): evidence for prograde metamorphism during subduction of oceanic crust. Am. Mineral. 99, 206-217. https://doi. org/10.2138/am.2014.4507.

Little, S.H., Vance, D., McManus, J., Severmann, S., 2016. Key role of continental margin sediments in the oceanic mass balance of $\mathrm{Zn}$ and $\mathrm{Zn}$ isotopes. Geology 44, 207-210. https://doi.org/10.1130/G37493.1.

Liu, S.-A., Li, S.-G., 2019. Tracing the deep carbon cycle using metal stable isotopes: opportunities and challenges. Engineering 5, 448-457. https://doi.org/10.1016/j eng.2019.03.007.

Liu, S.-A., Wang, Z.-Z., Li, S.-G., Huang, J., Yang, W., 2016. Zinc isotope evidence for a large-scale carbonated mantle beneath eastern China. Earth Planet. Sci. Lett. 444, 169-178. https://doi.org/10.1016/j.epsl.2016.03.051.

Mallik, A., Dasgupta, R., 2012. Reaction between MORB-eclogite derived melts and fertile peridotite and generation of ocean island basalts. Earth Planet. Sci. Lett. 329-330, 97-108. https://doi.org/10.1016/j.epsl.2012.02.007.

Mallmann, G., O'Neill, H.St.C., 2009. The crystal/melt partitioning of V during mantle melting as a function of oxygen fugacity compared with some other elements ( $\mathrm{Al}, \mathrm{P}$, $\mathrm{Ca}, \mathrm{Sc}, \mathrm{Ti}, \mathrm{Cr}, \mathrm{Fe}, \mathrm{Ga}, \mathrm{Y}, \mathrm{Zr}$ and Nb). J. Petrol. 50, 1765-1794. https://doi.org/10. 
1093/petrology/egp053

Maréchal, C.N., Télouk, P., Albarède, F., 1999. Precise analysis of copper and zinc isotopic compositions by plasma-source mass spectrometry. Chem. Geol. 156, 251-273. https://doi.org/10.1016/S0009-2541(98)00191-0.

Maréchal, C.N., Nicolas, E., Douchet, C., Albarède, F., 2000. Abundance of zinc isotopes as a marine biogeochemical tracer: ABUNDANCE OF ZINC ISOTOPES. Geochem. Geophys. Geosyst. 1. https://doi.org/10.1029/1999GC000029.

McCoy-West, A.J., Godfrey Fitton, J., Pons, M.-L., Inglis, E.C., Williams, H.M., 2018. The $\mathrm{Fe}$ and $\mathrm{Zn}$ isotope composition of deep mantle source regions: insights from Baffin Island picrites. Geochim. Cosmochim. Acta. https://doi.org/10.1016/j.gca.2018.07 021.

Moynier, F., Fujii, T., 2017. Calcium isotope fractionation between aqueous compounds relevant to low-temperature geochemistry, biology and medicine. Sci. Rep. 7, 44255. https://doi.org/10.1038/srep44255.

Moynier, F., Vance, D., Fujii, T., Savage, P., 2017. The isotope geochemistry of zinc and copper. Rev. Mineral. Geochem. 82, 543-600. https://doi.org/10.2138/rmg.2017. 82.13.

Nakamura, K., Kato, Y., 2004. Carbonatization of oceanic crust by the seafloor hydrothermal activity and its significance as a CO2 sink in the Early Archean. Geochim. Cosmochim. Acta 68, 4595-4618. https://doi.org/10.1016/j.gca.2004.05.023.

O'Neill, H.St.C., Eggins, S.M., 2002. The effect of melt composition on trace element partitioning: an experimental investigation of the activity coefficients of $\mathrm{FeO}, \mathrm{NiO}$, $\mathrm{CoO}, \mathrm{MoO} 2$ and MoO3 in silicate melts. Chem. Geol. 186, 151-181. https://doi.org/ 10.1016/S0009-2541(01)00414-4.

Palme, H., O'Neill, H.St.C., 2007. Cosmochemical estimates of mantle composition. In: Treatise on Geochemistry. Elsevier, pp. 1-38.

Patten, C., Barnes, S.-J., Mathez, E.A., Jenner, F.E., 2013. Partition coefficients of chalcophile elements between sulfide and silicate melts and the early crystallization history of sulfide liquid: LA-ICP-MS analysis of MORB sulfide droplets. Chem. Geol. 358, 170-188. https://doi.org/10.1016/j.chemgeo.2013.08.040.

Pertermann, M., 2003. Anhydrous partial melting experiments on MORB-like eclogite: phase relations, phase compositions and mineral-melt partitioning of major elements at 2-3 GPa. J. Petrol. 44, 2173-2201. https://doi.org/10.1093/petrology/egg074.

Pertermann, M., Hirschmann, M.M., 2003. Partial melting experiments on a MORB-like pyroxenite between 2 and $3 \mathrm{GPa}$ : constraints on the presence of pyroxenite in basalt source regions from solidus location and melting rate. J. Geophys. Res. Solid Earth 108. https://doi.org/10.1029/2000JB000118.

Petit, J.C.J., de Jong, J., Chou, L., Mattielli, N., 2008. Development of $\mathrm{Cu}$ and $\mathrm{Zn}$ isotope MC-ICP-MS measurements: application to suspended particulate matter and sediments from the scheldt estuary. Geostand. Geoanal. Res. 32, 149-166. https://doi. org/10.1111/j.1751-908X.2008.00867.x.

Pichat, S., Douchet, C., Albarède, F., 2003. Zinc isotope variations in deep-sea carbonates from the eastern equatorial Pacific over the last 175 ka. Earth Planet. Sci. Lett. 210, 167-178. https://doi.org/10.1016/S0012-821X(03)00106-7.

Plank, T., 2014. The chemical composition of subducting sediments. In: Treatise on Geochemistry. Elsevier, pp. 607-629. https://doi.org/10.1016/B978-0-08-095975-7. 00319-3.

Pons, M.-L., Debret, B., Bouilhol, P., Delacour, A., Williams, H., 2016. Zinc isotope evidence for sulfate-rich fluid transfer across subduction zones. Nat. Commun. 7, 13794. https://doi.org/10.1038/ncomms13794.

Pringle, E.A., Moynier, F., Savage, P.S., Jackson, M.G., Moreira, M., Day, J.M.D., 2016. Silicon isotopes reveal recycled altered oceanic crust in the mantle sources of Ocean Island Basalts. Geochim. Cosmochim. Acta 189, 282-295. https://doi.org/10.1016/j. gca.2016.06.008.

Prytulak, J., Elliott, T., 2007. TiO2 enrichment in ocean island basalts. Earth Planet. Sci. Lett. 263, 388-403. https://doi.org/10.1016/j.epsl.2007.09.015.

Ravna, E.K., Zozulya, D., Kullerud, K., Corfu, F., Nabelek, P.I., Janák, M., Slagstad, T., Davidsen, B., Selbekk, R.S., Schertl, H.-P., 2017. Deep-seated carbonatite intrusion and metasomatism in the UHP Troms $ø$ Nappe, Northern Scandinavian Caledonides-a natural example of generation of carbonatite from carbonated eclogite. J. Petrol. 58, 2403-2428. https://doi.org/10.1093/petrology/egy016.

Salters, V.J.M., Stracke, A., 2004. Composition of the depleted mantle. Geochem. Geophys. Geosyst. 5. https://doi.org/10.1029/2003GC000597.

Sanchez-Valle, C., Ghosh, S., Rosa, A.D., 2011. Sound velocities of ferromagnesian carbonates and the seismic detection of carbonates in eclogites and the mantle: ELASTICITY OF FERROMAGNESIAN CARBONATES. Geophys. Res. Lett. 38. https:// doi.org/10.1029/2011GL049981.

Savage, P.S., Georg, R.B., Williams, H.M., Burton, K.W., Halliday, A.N., 2011. Silicon isotope fractionation during magmatic differentiation. Geochim. Cosmochim. Acta 75, 6124-6139. https://doi.org/10.1016/j.gca.2011.07.043.

Schauble, E.A., 2004. Applying stable isotope fractionation theory to new systems. Rev. Mineral. Geochem. 55, 65-111. https://doi.org/10.2138/gsrmg.55.1.65.

Schilling, J.G., Zajac, M., Evans, R., Johnston, T., White, W., Devine, J.D., Kingsley, R., 1983. Petrologic and geochemical variations along the Mid-Atlantic Ridge from 29 degrees N to 73 degrees N. Am. J. Sci. 283, 510-586. https://doi.org/10.2475/ajs. 283.6.510.

Shaw, D.M., 1970. Trace element fractionation during anatexis. Geochim. Cosmochim. Acta 34, 237-243. https://doi.org/10.1016/0016-7037(70)90009-8.

Shimizu, K., Saal, A.E., Myers, C.E., Nagle, A.N., Hauri, E.H., Forsyth, D.W., Kamenetsky, V.S., Niu, Y., 2016. Two-component mantle melting-mixing model for the generation of mid-ocean ridge basalts: implications for the volatile content of the Pacific upper mantle. Geochim. Cosmochim. Acta 176, 44-80. https://doi.org/10.1016/j.gca. 2015.10.033.
Sobolev, A.V., Hofmann, A.W., Sobolev, S.V., Nikogosian, I.K., 2005. An olivine-free mantle source of Hawaiian shield basalts. Nature 434, 590-597. https://doi.org/10. 1038/nature03411.

Sobolev, A.V., Hofmann, A.W., Kuzmin, D.V., Yaxley, G.M., Arndt, N.T., Chung, S.-L., Danyushevsky, L.V., Elliott, T., Frey, F.A., Garcia, M.O., et al., 2007. The amount of recycled crust in sources of mantle-derived melts. Science 316, 412-417.

Sossi, P.A., Halverson, G.P., Nebel, O., Eggins, S.M., 2015. Combined separation of Cu, Fe and $\mathrm{Zn}$ from rock matrices and improved analytical protocols for stable isotope determination. Geostand. Geoanal. Res. 39, 129-149. https://doi.org/10.1111/j.1751 908X.2014.00298.x.

Sossi, P.A., Nebel, O., O'Neill, H.St.C., Moynier, F., 2018. Zinc isotope composition of the Earth and its behaviour during planetary accretion. Chem. Geol. 477, 73-84. https:// doi.org/10.1016/j.chemgeo.2017.12.006.

Spandler, C., Yaxley, G., Green, D.H., Scott, D., 2010. Experimental phase and melting relations of metapelite in the upper mantle: implications for the petrogenesis of intraplate magmas. Contrib. Mineral. Petrol. 160, 569-589. https://doi.org/10.1007/ s00410-010-0494-2.

Staudigel, H., Davies, G.R., Hart, S.R., Marchant, K.M., Smith Brian, M., 1995. Large scale isotopic Sr, Nd and O isotopic anatomy of altered oceanic crust: DSDP/ODP sites417/ 418. Earth Planet. Sci. Lett. 130, 169-185. https://doi.org/10.1016/0012-821X(94) 00263-X.

Steinberger, B., 2000. Plumes in a convecting mantle: models and observations for individual hotspots. J. Geophys. Res. 105, 11127-11152. https://doi.org/10.1029/ 1999JB900398.

Stracke, A., Hofmann, A.W., Hart, S.R., 2005. FOZO, HIMU, and the rest of the mantle zoo. Geochem. Geophys. Geosyst. 6. https://doi.org/10.1029/2004GC000824.

Sweeney, R.J., Prozesky, V., Przybylowicz, W., 1995. Selected trace and minor element partitioning between peridotite minerals and carbonatite melts at $18-46 \mathrm{~kb}$ pressure. Geochim. Cosmochim. Acta 59, 3671-3683. https://doi.org/10.1016/0016-7037(95) 00270-A.

Teng, F.-Z., Dauphas, N., Helz, R.T., 2008. Iron isotope fractionation during magmatic differentiation in Kilauea Iki Lava Lake. Science 320, 1620-1622. https://doi.org/10. 1126/science.1157166.

Urann, B.M., Le Roux, V., John, T., Beaudoin, G.M., Barnes, J.D., 2020. The distribution and abundance of halogens in eclogites: an in situ SIMS perspective of the Raspas complex (Ecuador). Am. Mineral. 105, 307-318. https://doi.org/10.2138/am-20206994.

Urey, H.C., 1947. The thermodynamic properties of isotopic substances. J. Chem. Soc 562. https://doi.org/10.1039/jr9470000562.

Walter, M.J., 1998. Melting of garnet peridotite and the origin of komatiite and depleted lithosphere. J. Petrol. 39, 29-60. https://doi.org/10.1093/petroj/39.1.29.

Wang, Z.-Z., Liu, S.-A., Liu, J., Huang, J., Xiao, Y., Chu, Z.-Y., Zhao, X.-M., Tang, L., 2017. Zinc isotope fractionation during mantle melting and constraints on the $\mathrm{Zn}$ isotope composition of Earth's upper mantle. Geochim. Cosmochim. Acta 198, 151-167. https://doi.org/10.1016/j.gca.2016.11.014.

Wasylenki, L.E., 2003. Near-solidus melting of the shallow upper mantle: partial melting experiments on depleted peridotite. J. Petrol. 44, 1163-1191. https://doi.org/10. 1093/petrology/44.7.1163.

Weaver, B.L., 1991. The origin of ocean island basalt end-member compositions: trace element and isotopic constraints. Earth Planet. Sci. Lett. 104, 381-397. https://doi. org/10.1016/0012-821X(91)90217-6.

Willbold, M., Stracke, A., 2006. Trace element composition of mantle end-members: implications for recycling of oceanic and upper and lower continental crust. Geochem. Geophys. Geosyst. 7. https://doi.org/10.1029/2005GC001005.

Williams, H.M., Bizimis, M., 2014. Iron isotope tracing of mantle heterogeneity within the source regions of oceanic basalts. Earth Planet. Sci. Lett. 404, 396-407. https://doi. org/10.1016/j.epsl.2014.07.033.

Williams, H.M., Nielsen, S.G., Renac, C., Griffin, W.L., O’Reilly, S.Y., McCammon, C.A., Pearson, N., Viljoen, F., Alt, J.C., Halliday, A.N., 2009. Fractionation of oxygen and iron isotopes by partial melting processes: Implications for the interpretation of stable isotope signatures in mafic rocks. Earth Planet. Sci. Lett. 283, 156-166. https://doi. org/10.1016/j.epsl.2009.04.011.

Wood, B.J., Blundy, J.D., 2002. The effect of $\mathrm{H} 2 \mathrm{O}$ on crystal-melt partitioning of trace elements. Geochim. Cosmochim. Acta 66, 3647-3656. https://doi.org/10.1016/ S0016-7037(02)00935-3.

Wood, B.J., Kiseeva, E.S., 2015. Trace element partitioning into sulfide: how lithophile elements become chalcophile and vice versa. Am. Mineral. 100, 2371-2379. https:// doi.org/10.2138/am-2015-5358CCBYNCND.

Xu, L., Liu, S.A., 2018. Zinc Isotopic Behavior during Continental Subduction Recorded by Metamorphic Rocks. (AGU Fall Meeting Abstracts).

Yang, Z.-F., Li, J., Liang, W.-F., Luo, Z.-H., 2016. On the chemical markers of pyroxenite contributions in continental basalts in Eastern China: implications for source lithology and the origin of basalts. Earth Sci. Rev. 157, 18-31. https://doi.org/10. 1016/j.earscirev.2016.04.001.

Yaxley, G.M., Brey, G.P., 2004. Phase relations of carbonate-bearing eclogite assemblages from 2.5 to $5.5 \mathrm{GPa}$ implications for petrogenesis of carbonatites. Contrib. Mineral Petrol. 146, 606-619. https://doi.org/10.1007/s00410-003-0517-3.

Zack, T., Tomascak, P.B., Rudnick, R.L., Dalpé, C., McDonough, W.F., 2003. Extremely light $\mathrm{Li}$ in orogenic eclogites: the role of isotope fractionation during dehydration in subducted oceanic crust. Earth Planet. Sci. Lett. 208, 279-290. https://doi.org/10. 1016/S0012-821X(03)00035-9.

Zindler, A., Hart, S., 1986. Chemical geodynamics. Annu. Rev. Earth Planet. Sci. 14, 493-571. https://doi.org/10.1146/annurev.ea.14.050186.002425. 